\title{
Ocena sprawności polskiego powojennego wymiaru sprawiedliwości w osądzaniu zbrodni prawa międzynarodowego na przykładzie prac wykonanych przez Główną Komisję Badania Zbrodni Niemieckich w Polsce na terenie obozu karno-śledczego w Żabikowie i wykorzystania ich w procesie Arthura Greisera
}

Polska jako jedna z pierwszych ofiar III Rzeszy podejmowała, przez przedstawicieli rządu przebywającego na emigracji w Londynie, działania mające na celu ściganie zbrodniarzy i osądzanie zbrodni prawa międzynarodowego. Z inicjatywy Polski i Czechosłowacji 13 stycznia 1942 r. doszło do zorganizowania konferencji w pałacu St. James, której obradom przewodniczył polski premier gen. Władysław Sikorski. W kończącej ją deklaracji wskazano potrzebę ukarania winnych zbrodni prawa międzynarodowego. Po kolejnych mniejszych inicjatywach, takich jak Deklaracja w sprawie prześladowania Żydów ministra sprawa zagranicznych Wielkiej Brytanii Anthonego Edena, przedstawiciele „wielkiej trójki”1, podpisali Deklarację Moskiewską. Dokument ten stał się podstawą do ścigania i karania zbrodniarzy hitlerowskich, zarówno w samych Niemczech, jak i w krajach okupowanych. Kluczowe postanowienie Deklaracji brzmi:

Z chwilą zawarcia jakiegokolwiek rozejmu z jakimkolwiek rządem, który będzie wówczas w Niemczech, ci niemieccy oficerowie i żołnierze, a także członkowie partii nazistowskiej, którzy są odpowiedzialni lub brali udział we wspomnianych okrucieństwach, masakrach i egzekucjach, zostaną wydani państwom, w których dopuścili się swoich ohydnych zbrodni, w celu osądzenia i ukarania zgodnie z prawami tych państw i ich wolnych rządów².

${ }^{1}$ Wielka trójka to pojęcie odnoszące się do przywódców trzech mocarstw światowych, współpracujących w ramach koalicji antyhitlerowskiej. Józef Stalin, Winston Churchill (zastąpiony po przegranych wyborach przez Clementa Attlee) i Franklin Delano Roosevelt (po którego śmierci obowiązki przejął następca - Harry Truman).

2 T. Cyprian, J. Sawicki, Prawo Norymberskie - bilans i perspektywy, Warszawa 1948, s. 101. 
Kwestia wydania podejrzanych o popełnienie zbrodni ma swój wyjątek w postaci „głównych przestępców wojennych”, którzy osądzeni zostali w Niemczech przed Międzynarodowym Trybunałem Wojskowym.

Długie debaty dotyczące kwalifikacji przestępstw, a także spory sięgające podstaw prawa, wyrażonych w zasadach nullum crimen sine lege, a także lex retro non agit, zostały przezwyciężone, co zaowocowało powstaniem Międzynarodowego Trybunału Wojskowego. Tadeusz Cyprian i Jerzy Sawicki wskazują, że w toku pracy i dyskusji wyłoniły się trzy kategorie przestępstw:

Naruszenie praw i zwyczajów wojennych, czyli zbrodnie wojenne w ścisłym tego słowa znaczeniu, planowanie, wszczęcie i prowadzenie wojny zaczepnej, czyny dokonywane także przed rozpoczęciem wojny, ale sprzeczne z elementarnymi zasadami prawnymi, obowiązującymi cywilizowane narody, czyli przestępstwa przeciwko ludzkości³ .

Krótko po zakończeniu działań wojennych w Europie, 6 lipca 1945 r. Wielka Brytania i Stany Zjednoczone wycofały poparcie dla Rządu Londyńskiego i za prawowite polskie władze uznały Tymczasowy Rząd Jedności Narodowej ${ }^{4}$ w Warszawie. Już 25 września 1945 r. TRJN przystąpił do Porozumienia Londyńskiego ${ }^{5}$, co wiązało się z udziałem w pracach przygotowujących powstanie Międzynarodowego Trybunału Wojskowego. Zarówno Rząd Londyński, jak i polskie władze komunistyczne, wyrażały zbieżny pogląd co do konieczności ścigania i sądzenia zbrodniarzy prawa międzynarodowego. Jednak, jak pokazały wydarzenia końca lat wojennych, odpowiedzialność ta spadła na władze komunistyczne, czy to działające jako Krajowa Rada Narodowa, czy później jako Tymczasowy Rząd Jedności Narodowej z symbolicznym udziałem opozycji.

Jeszcze przed zakończeniem działań wojennych, kiedy nad Sprewą walczyli ostatni niemieccy żołnierze, w Polsce kształtować się zaczął system ścigania i sądzenia zbrodniarzy wojennych. Trudno z dzisiejszej perspektywy ocenić, czy został on w pełni zaplanowany, czy też był raczej wynikiem nieskoordynowanych działań różnych podmiotów, jednak powojenny chaos, także w zakresie legislacyjnym, skłania raczej do podejrzeń, że bliższa prawdy pozostaje ta druga możliwość.

3 T. Cyprian, J. Sawicki, Ludzie i sprawy Norymbergi, Poznań 1967, s. 52.

${ }^{4}$ Tymczasowy Rząd Jedności Narodowej wyłonił się z Krajowej Rady Narodowej, organu Polskiej Partii Robotniczej. Skład rządu zdominowany został przez działaczy komunistycznych 7 osób, a także socjalistów z PPS, którzy pozostawali jednak zależni od PPR. W rządzie znalazły się także dwie osoby ze Stronnictwa Ludowego ze Stanisławem Mikołajczykiem na czele, stanowiącego krótko po wojnie jedyną liczącą się siłę opozycyjną.

${ }^{5}$ Porozumienie międzynarodowe w przedmiocie ścigania i karania głównych przestępców wojennych Osi Europejskiej, Karta Międzynarodowego Trybunału Wojskowego, Londyn, 8 sierpnia 1945 r. (Dz.U. z 1947 r. nr 63, poz. 367). 
Przykład badania zbrodni popełnionych w obozie karno-śledczym w Żabikowie, a także związana z nimi sprawa Arthura Greisera, pozwolą przyjrzeć się procesowi sądzenia najważniejszych zbrodniarzy wojennych na terytorium RP, a przede wszystkim odpowiedzieć na pytanie, czy nowym polskim władzom udało się zorganizować sprawnie działający system, mający czynić zadość wskazanym wyżej potrzebom. Należy rozważyć też, biorąc pod uwagę skrajnie trudne warunki powojenne, czy sprawność wytworzonego systemu była wystarczająca, oraz czy działał on na zasadach sprawiedliwości i demokracji, zgodnie z ich dzisiejszym pojmowaniem. By odpowiedzieć na te pytania, należy skupić się na składowych systemu, od których funkcjonowania zależał finalny efekt, tj. podstawie prawnej, panujących warunkach, a także umiejętności współpracy pomiędzy różnymi podmiotami. Rezultatem spójności i prawidłowego działania wskazanych wyżej czynników było ekstradowanie do Polski najważniejszych podejrzanych, zebranie wystarczająco wielu mocnych dowodów, by sformułować akty oskarżenia, a następnie przeprowadzenie procesów sądowych.

Jako pierwszą część składową wymienić należy prokuraturę, która działała w oparciu o przedwojenne ustawy Kodeks karny z 1932 r. ${ }^{6}$ i Kodeks postępowania karnego z 1929 r. ${ }^{7}$ Kolejnym ważnym elementem, stworzonym także po to, by prowadzić badania i zbierać dowody, wykorzystywane następnie do sporządzania aktu oskarżenia, była Główna Komisja Badania Zbrodni Niemieckich w Polsce, a także jej ekspozytura w Niemczech, której zadaniem było prowadzenie procesów ekstradycyjnych. Na końcowym etapie całego procesu był Najwyższy Trybunał Narodowy - specjalny sąd, którego właściwość obejmowała przestępstwa określone w Deklaracji moskiewskiej i Dekrecie z 22 stycznia 1946 r. ${ }^{8}$

By właściwie zacząć rozważania na temat procesu Arthura Greisera i oceny sprawności polskiego wymiaru sprawiedliwości w osądzaniu zbrodni prawa międzynarodowego, należy cofnąć się do jednej z nich. Obóz karno-śledczy w Żabikowie łączy się nierozerwalnie z pozostałymi miejscami kaźni polskich obywateli, zamieszkujących Wielkopolskę w okresie drugiej wojny światowej. Obóz ten, jako jedno z najważniejszych miejsc wielkopolskiej martyrologii okresu II wojny światowej, wielokrotnie pojawia się w toku procesu karnego Arthura Greisera. Zbrodnie tam popełnione stały się jedną z podstaw przedstawienia byłemu gauleiterowi Kraju Warty aktu oskarżenia, będącego efektem współpracy prokuratury i Głównej Komisji Badania Zbrodni Niemieckich w Polsce.

\footnotetext{
${ }^{6}$ Dz.U. z 1932 r. nr 60, poz. 517.

7 Dz.U. z 1928 r. nr 33, poz. 313.

${ }^{8}$ Dz.U. z 1946 r. nr 5, poz. 46, Dekret z dnia 22 stycznia 1946 r. o odpowiedzialności za klęskę wrześniową i faszyzację życia państwowego.
} 
Początkowo naturalnym miejscem przetrzymywania skazanych było więzienie przy ul. Młyńskiej w Poznaniu, które przejęte zostało przez władze hitlerowskie od Polaków tuż po zdobyciu miasta we wrześniu 1939 r. Także więzienie utworzone w Tamie Berdychowskiej i areszt Gestapo w Domu Żołnierza ${ }^{9}$ budziły grozę wśród mieszkańców Kraju Warty. Jednakże aparat państwowy III Rzeszy potrzebował więcej miejsca dla przetrzymywania podejrzanych i skazanych za przestępstwa polityczne, gospodarcze i kryminalne. Właśnie $\mathrm{z}$ tego powodu wykorzystano dawny pruski Fort VII, usytuowany pomiędzy poznańskimi dzielnicami Ogrody i Wola. Pierwsze narady i decyzje w sprawie utworzenia obozu koncentracyjnego miały miejsce już 25 września 1939 r. ${ }^{10} \mathrm{~W}$ latach okupacji niemieckiej Fort VII przechodził szereg zmian organizacyjnych i określany był mianem obozu koncentracyjnego, więzienia policyjnego Gestapo i obozu wychowawczego. Znawca tematu Marian Olszewski wskazuje jednak, że od początku do końca swojego istnienia Fort VII był obozem przejściowym ${ }^{11}$.

Wraz z atakiem III Rzeszy na Związek Radziecki w czerwcu 1941 r. pojawiła się potrzeba wykorzystania Fortu VII zgodnie z jego militarnym przeznaczeniem. Pierwotne plany rozbudowy zarzucono i podjęto decyzję o oddaniu Wehrmachtowi pruskich zabudowań fortecznych i wybudowaniu nowego obozu przejściowego. Proces ten był jednak bardzo powolny i właściwe przenoszenie więźniów, wraz z ruchomą infrastrukturą, rozpoczęło się dopiero wiosną 1943 r. Początkowo obóz powstać miał w podpoznańskiej wówczas Starołęce i pomieścić około 800 więźniów, strzeżonych przez 100 -osobową załogę ${ }^{12}$. Do dziś zachowały się jego plany ${ }^{13}$, na podstawie których rozpoczęto budowę. Zarówno przeznaczenie, jak i wielkość obozu były kilkakrotnie zmieniane. Zmniejszano liczbę baraków, urządzeń sanitarnych, aż w końcu decyzją z 16 grudnia 1942 r., Urząd Reichsstatthaltera wskazał, że zamiast budować nowy obóz dla oszczędności wykorzysta się baraki zamieszkiwane do tej pory przez Żydów, którzy w ramach pracy przymusowej budowali autostradę w podpoznańskim Żabikowie ${ }^{14}$. Jak wskazują dokumenty, była to decyzja jak najbardziej uzasadniona i logiczna, gdyż zamiast planowanych 1400000 wydano jedynie 130500 marek $^{15}$.

9 S. Datner, Wilhelm Koppe - nieukarany zbrodniarz hitlerowski, Warszawa 1963, s. 24.

10 M. Olszewski, Fort VII w Poznaniu, Poznań 1971, s. 7.

${ }^{11}$ Ibidem, s. 18.

${ }^{12}$ Archiwum Państwowe Poznań, Reichsstatthalter im Reichsgau Wartherland, sygn. 2958, k. 3-6.

13 Ibidem.

${ }_{14}$ B. Bojarska, Obóz w Żabikowie pod Poznaniem, „Przegląd Zachodni” 1965, r. XXI, t. I, nr 1-2, s. 298. k. 3-6.

${ }^{15}$ Archiwum Państwowe Poznań, Reichsstatthalter im Reichsgau Wartherland, sygn. 2958, 
W okolicach późniejszego obozu karno-śledczego funkcjonowały dwa obozy przeznaczone dla ludności żydowskiej. Jak wspomina Stanisław Malepszak, jeden z nich usytuowany był na południe od ul. Samotnej na poznańskim Dębcu, a drugi przy dzisiejszej ul. Kościuszki w Luboniu, gdzie obecnie stoją bloki mieszkalne ${ }^{16}$. Zatem jeszcze zanim do Żabikowa trafili pierwsi więźniowie z Fortu VII (który jako więzienie funkcjonował do 27 kwietnia 1944 r.), działał tam tzw. „obóz autostradowy", czyli jedno z miejsc prac przymusowych dla ludności żydowskiej, wchodzące w skład całego ciągu obozów, które usytuowane były wzdłuż budowanych arterii ${ }^{17}$. Prace nad powstaniem autostrady pomiędzy Luboniem a Żabikowem rozpoczęto wiosną 1941 r., a przywożeni z całej Wielkopolski Żydzi stłoczeni zostali w pięciu barakach i zmuszeni do katorżniczej pracy, początkowo przy budowie linii kolejowej, mającej służyć do przywożenia zaopatrzenia, a następnie przy budowie arterii prowadzącej na wschód ${ }^{18}$. Realizację pomysłu utworzenia autostrady, także z powodów finansowych, zakończono w 1942 r. i zdecydowano o likwidacji „obozu autostradowego”, wywożąc pozostałych przy życiu, wycieńczonych Żydów do obozów koncentracyjnych.

Wykorzystanie lokalizacji zbliżonej do funkcjonujących do niedawna obozów dla ludności żydowskiej, mimo wspomnianych oszczędności, miało jednak kilka wad: sporą odległość od siedziby policji w Poznaniu, brak przeładunkowej stacji kolejowej (co rozwiązane zostało z czasem dzięki pracy więźniów) i gęstą jak na wiejskie warunki zabudowę ${ }^{19}$. Z ostatnią z wymienionych niedogodności poradzono sobie dokonując wysiedleń z domów znajdujących się w najbliższym sąsiedztwie obozu.

Prace nad powstaniem obozu karno-śledczego w Żabikowie (Polizeigefängnis der Sicherheitspolizeiund Arbeitserziehungslager Posen-Lenzingen) rozpoczęto pod koniec 1942 r., wykorzystując do tego więźniów z Fortu VII, a także okolicznych mieszkańców. Na 3 stycznia 1943 r. datowane jest pismo, skierowane do Gestapo, które zawiera informację, że proces budowy obozu w Żabikowie dobiega końca ${ }^{20}$. Obóz karno-śledczy powstał z wykorzystaniem zabudowań baraków przeznaczonych dla Żydów na terenach nieczynnej cegielni w pobliżu ul. Kotowo. Otoczony został podwójnym ogrodzeniem z drutu kolczastego, wzmocnionym zasiekami podłączonymi do prądu elektrycznego i dwiema wie-

16 S. Malepszak, Żabikowo - dzieje wsi i fundacji Augusta Cieszkowskiego, Luboń 1990, s. 84.

${ }^{17}$ A. Ziółkowska, Obozy pracy przymusowej dla Żydów $w$ Wielkopolsce w latach okupacji hitlerowskiej (1941-1943), Poznań, s. 104.

18 S. Malepszak, op.cit., s. 8386.

${ }_{19}$ M. Olszewski, Żabikowo Hitlerowski Obóz Karny w Żabikowie koło Poznania, Poznań 1979, s. 2.

${ }^{20}$ Archiwum Państwowe Poznań, Reichsstatthalter im Reichsgau Wartherland, sygn. 2958, k. 3-6. 
żami strażniczymi. W dość krótkim czasie wzniesione zostały niezbędne zabudowania, potrzebne do funkcjonowania obozu, takie jak murowana komendantura, kuchnia, łaźnia, stajnia, bunkier, magazyny, warsztaty, karcer i drewniane baraki - sześć dla mężczyzn i dwa dla kobiet. Zabudowania, do których trafiali więźniowie podzielone były na „polityczne” i „,wychowawcze” (karne). Osobną grupę stanowili „niedzielniacy”, tj. więźniowie przebywający w obozie od soboty wieczór do poniedziałku rano, których poddawano ,przemusztrowaniu”21, a którzy trafiali do obozu na podstawie donosu. Była to zwykle młodzież, podejrzana o drobne wykroczenia, związane ze źle wykonywaną pracą przymusową. Do Żabikowa trafiali w znakomitej większości Polacy - kobiety ${ }^{22}$ i mężczyźni w różnym wieku, ale także osoby innych narodowości, przeciwko którym prowadzone było śledztwo w Poznaniu, w tym jeńcy radzieccy, amerykańscy, ale także niemieccy dezerterzy.

Obóz karno-śledczy w Żabikowie podlegał placówce kierowniczej Tajnej Policji Państwowej w Poznaniu (Geheime Staatspolizeileitstelle, Gestapo), a swoim zasięgiem obejmował obszar rejencji poznańskiej i częściowo inowrocławskiej, będących częścią Kraju Warty²3. Do Żabikowa w znakomitej większości trafiali więźniowie polityczni, przeciwko którym śledztwo prowadziło Gestapo. Zatem po przesłuchaniach w siedzibie Tajnej Policji (dzisiejszym Domu Żołnierza na ul. Niezłomnych w Poznaniu), którym najczęściej towarzyszyły wymyślne tortury ${ }^{24}$, podejrzany trafiał do obozu karno-śledczego. Pobyt w Żabikowie trwał najczęściej od kilku do kilkunastu dni, z wyłączeniem grupy „niedzielniaków”. Pomimo że zdarzało się, że po pobycie w obozie karno-śledczym podejrzani odzyskiwali wolność, to w większości przypadków transportowani byli do obozów koncentracyjnych albo umierali w wyniku skrajnie trudnych warunków życia, katorżniczej pracy czy sadyzmu strażników.

Więźniowie wykonywali prace dla różnych okolicznych zakładów, takich jak huta szkła w Antoninku czy fabryka H. Ciegielskiego (Deutsche Waffen und Munitionsfabriken $A G$ ), budując też schrony lotnicze, wypalając cegły, remontując lotnisko Ławica, a także wykonując prace wewnątrz obozu, które niestety w pewnym stopniu sprowadzały się do zadań bezsensownych, mających na celu tylko udręczenie osadzonych ${ }^{25}$. Warunki, w jakich przetrzymywani byli więźniowie, określić należy jako skrajnie trudne i nieodbiegające od standardów obozów koncentracyjnych. Zatłoczone, słabo ogrzewane baraki, dokuczające osadzonym

${ }^{21}$ K. Płonka, Martyrologium obozu hitlerowskiego w Żabikowie 1943-1945, Luboń 2004, s. 5.

22 A. Markwitz-Bielerzewska, Wspomnienia więźniarki Żabikowa, Żabikowo 2011.

${ }^{23}$ K. Płonka, op.cit., s. 4.

${ }^{24}$ E. Serwański, Wielkopolska w cieniu swastyki, Warszawa 1970, s. 94.

${ }^{25}$ M. Olszewski, Żabikowo Hitlerowski Obóz Karny w Żabikowie koło Poznania, Poznań 1979, s. 6-7. 
insekty, bardzo skromne racje żywnościowe, a także nieludzkie traktowanie przyczyniały się do cierpień więźniów i wysokiej umieralności ${ }^{26}$. Naruszenia regulaminu obozowego czy po prostu decyzja któregoś ze strażników obozu, jak wynika z ustaleń poczynionych przez prokuratorów Najwyższego Trybunału Narodowego, kończyły się pobytami we wspólnych karcerach, gdzie przez ograniczoną liczbę miejsca oraz przepływający przez druty prąd elektryczny, osadzeni musieli trwać w pozycji wymuszonej. W miejscu takim, jak wynika z uzasadnienia aktu oskarżenia przeciwko Arthurowi Greiserowi, „umieszczano po 25-30 więźniów, skulonych w pozycji leżącej i skutych łańcuchami za szyję w ten sposób, że gdy jeden z nich dotknął zawieszonej na wysokości wzrostu człowieka siatki naładowanej elektrycznością, wówczas prąd raził wszystkich”27. Były też karcery pojedyncze, stanowiące zwinięty w kształt walca drut kolczasty, we wnętrzu którego, karany pozbawiony jedzenia i picia, musiał przez wiele dni utrzymywać pozycję stojącą ${ }^{28}$.

Wraz ze zbliżaniem się frontu, 19 stycznia 1945 r. rozpoczęła się likwidacja obozu ${ }^{29}$. Więźniów, w liczbie około 120 osób $^{30}$, zebrano w kolumny i popędzono w kierunku zachodnim, gdzie trafili do obozu koncentracyjnego Oranienburg-Sechsenhausen. Równocześnie esesmani pełniący rolę strażników wtłoczyli wszystkich pozostałych, którzy ze względu na stan zdrowia nie wytrzymaliby trudów podróży, do największego baraku i podpalili. Zginęło w ten sposób od kilkudziesięciu do ponad stu ludzi. W pośpiechu, także przy pomocy ognia, zniszczona została dokumentacja obozu.

Ustalenie dokładnej liczby osób, które straciły życie w obozie karno-śledczym w Żabikowie było już przedmiotem wielu badań, opartych o akty zgonu wystawiane przez administrację niemiecką, orzeczenia sądowe spraw o uznanie za zmarłego już po wojnie, pochówki na cmentarzu żabikowskim, zwłoki odnalezione w Collegium Anatomicum, wykorzystywane przez Niemców do badań naukowych, czy ciała osadzonych odnalezione po likwidacji obozu w Żabikowie. Stanisław Nawrocki przyjął, że w obozie zginąć mogło nawet 20 tysięcy osób ${ }^{31}$. Marian Olszewski w swym opracowaniu o stratach ludności Poznania w czasie okupacji znacznie zredukował tę liczbę, do maksymalnie $4000^{32}$. Tematem tym

${ }^{26}$ A. Wietrzykowski, Zbrodnie niemieckie w Żabikowie, Poznań 1946, s. 18.

${ }_{27}$ Proces Arthura Greisera przed Najwyższym Trybunałem Narodowym, Warszawa 1946, s. 35.

${ }^{28}$ L. Gomolec, S. Kubiak, Terror hitlerowski w Wielkopolsce, Poznań 1962, s. 24

29 J. Majerus, Ewakuacja Obozu w Żabikowie w 1945 r., Luboń 2003.

${ }^{30}$ S. Malepszak, op.cit., s. 92-95.

${ }^{31}$ S. Nawrocki, Policja hitlerowska w tzw. Kraju Warty w latach 1939-1945, Poznań 1970, s. 213.

${ }_{32}$ M. Olszewski, Straty i martyrologia ludności polskiej w Poznaniu 1939-1945, Poznań 1973, s. 164. 
zajmowali się także Czesław Pilichowski ${ }^{33}$ i Andrzej Strzelecki ${ }^{34}$, jednak podawane przez nich liczby dotyczą ogółu więźniów i samych transportów. Przełomu we wskazaniu właściwej liczby osób zmarłych czy zamordowanych w obozie karno-śledczym dokonał w latach osiemdziesiątych Marian Woźniak ${ }^{35}$, który wskazał, że w Żabikowie życie straciło nie więcej niż 400 osób. Bliski tego ustalenia jest też Krzysztof Płonka, sumujący akty zgonu wystawione przez Niemców, orzeczenia sądowe o uznaniu za zmarłych i 67 niezidentyfikowanych dotąd ciał, podając ostateczną liczbę 535 osób. Marian Woźniak określił też łączną liczbę 21624 osób, które przewinęły się przez obóz karno-śledczy w Żabikowie ${ }^{36}$.

Pierwsze oględziny obozu w Żabikowie odbyły się bezpośrednio po wyzwoleniu Poznania - w lutym 1945 r. Obecny na miejscu Wojskowy Prokurator Garnizonu w Poznaniu mjr I. Iwanow wskazywał, że przez obóz przejść mogło około 40 tysięcy ludzi. Odkryto jednocześnie spalone ludzkie szczątki i bezimienne zbiorowe mogiły. Mjr Iwanow w swym raporcie do Wojskowego Prokuratora Poznańskiego Okręgu Wojskowego WP informował też o przeprowadzeniu wywiadu z lokalną społecznością, wskazując jednocześnie, że zasadne jest podjęcie szczegółowego śledztwa na temat żabikowskiego obozu, którego on sam, z uwagi na „bieżące obciążenie sprawami śledczymi”, nie jest w stanie nadzorować ${ }^{37}$. Po około miesiącu od wizyty prok. I. Iwanowa w Żabikowie, dnia 24 marca 1945 r. powołano komisję, która dokonać miała pierwszych ustaleń dotyczących obozu ${ }^{38}$. W jej skład weszli dr S. Babski z PCK, A. Wietrzykowski jako przedstawiciel prasy, a także lokalni działacze Polskiej Partii Robotniczej, przedstawiciel Urzędu Bezpieczeństwa, wójt gminy Żabikowo i tamtejszy Komendant Milicji Obywatelskiej. Na wstępie odkryto ok. 160 rozkładających się ciał osób spalonych żywcem podczas ewakuacji. Ponadto na podstawie zeznań świadków i pozostałości zabudowań dokonano pierwszych pomiarów i ustaleń, a także wyciągnięto wstępne wnioski na temat organizacji i warunków panujących w obozie ${ }^{39}$. Raport sporządzony przez komisję w oparciu o oględziny i wywiad z byłymi więźniami był dalece bardziej szczegółowy i dokładny od sprawozdania prok. Iwanowa, jednakże nadal przeprowadzony w sposób mający charakter społecznikowski, stanowiący tak naprawdę wstęp do badań. Oszacowano, że w obozie znajdowało się

${ }^{33}$ Cz. Pilichowski, Fatszerstwo czy prowokacja? Odwetowcy w roli oskarżycieli, Warszawa 1977, s. 85.

${ }^{34}$ A. Strzelecki, Ewakuacja, likwidacja i wyzwolenie KL Auschwitz, Oświęcim 1982, s. 100.

${ }^{35}$ M. Woźniak, Więźniowie więzienia policyjnego poznańskiego gestapo w latach 1943-1945, „Kronika Wielkopolski” 1985, nr 1, s. 175-176.

${ }^{36}$ Ibidem.

37 IPN GK 178/127, k. 1.

${ }^{38}$ Ibidem, k. 2.

39 A. Wietrzykowski, op.cit., s. 7-9. 
przeciętnie około 1700 osadzonych, którzy stłoczeni zostali w ośmiu barakach. Ponadto barwnie opisano skrajnie trudne warunki bytowe, urągające podstawowym zasadom higieny ${ }^{40}$, a także podjęto temat skromnych racji żywnościowych oraz przypadków bicia i znęcania się nad więźniami.

Dnia 6 maja 1945 o godzinie 11:30, w gabinecie prokuratora Specjalnego Sądu Karnego w Poznaniu, w gmachu Sądu Grodzkiego przy ul. Młyńskiej, obyło się pierwsze zebranie ${ }^{41}$, którego celem było wszczęcie profesjonalnych prac ekshumacyjnych i śledczych prowadzonych pod nadzorem prokuratora. Na zaproszenie Wacława Jonsika przybyli: lekarz dr Stanisław Łaguna - adiunkt Uniwersytetu Poznańskiego, sędzia śledczy Józef Rzędowski, asesor Alfons Lehmann, wiceprokurator Stanisław Mojkowski oraz przedstawiciel Urzędu Wojewódzkiego w Poznaniu, wysłannik Urzędu Informacji i Propagandy i członek Polskiego Związku Zachodniego. Prokurator W. Jonsik wskazał, iż zadaniem Komisji będzie „ustalenie stanu faktycznego zbrodni niemieckich oraz sposobu dręczenia ofiar tam więzionych i zarazem udokumentowanie ofiar, jakie Naród Polski w czasie wojny poniósł" ${ }^{2}$. Cel ten miał zostać zrealizowany przez dotarcie do możliwie największej liczby świadków, a także przez dokładne oględziny pozostałości zabudowy obozu i prace ekshumacyjne. Ważną kwestią dla osób tworzących komisję do zbadania zbrodni niemieckich na terenie obozu w Żabikowie było nagłośnienie prowadzonych prac celem pozyskania informacji od jak największej liczby osób mających wiadomości na temat obozu, a także ewentualnej pomocy rodzinom poszukującym swoich bliskich. Zadanie to zrealizowane zostać miało dzięki Agencji Polpress i redakcji „Głosu Wielkopolskiego" ${ }^{\text {43 }}$. W toku rozmów prowadzonych na zebraniu pojawiły się propozycje, by zasięg prac komisji rozszerzyć na całą Wielkopolskę, jednak zapędy te hamował dr S. Łaguna, wskazując na szczupłość kadr i ogrom ewentualnych czynności, jakie stanęłyby przed komisją. Na koniec zebrania prokurator W. Jonsik wskazał pięciodniowy termin na zebranie koniecznego sprzętu, od aparatów fotograficznych po ciężarówki, i wyznaczył datę kolejnego spotkania na 14 maja $1945 \mathrm{r}$.

Tego dnia zawiązana świeżo komisja spotkała się w podobnym gronie, $\mathrm{z}$ tą różnicą, że dodatkowo pojawili się przedstawiciel kurii poznańskiej ks. dr Jan Noryśkiewicz oraz Czesław Pilichowski, późniejszy dyrektor Głównej Komisji Badania Zbrodni Hitlerowskich w Polsce. Po przedstawieniu zaawansowania prac przygotowawczych, głos zabrał Stanisław Łaguna, który przybliżył pozostałym uczestnikom zebrania techniczne szczegóły prowadzenia prac ekshumacyjnych ${ }^{44}$.

\footnotetext{
${ }^{40}$ IPN GK 178/127, k. 2-3.

${ }^{41}$ IPN GK 196/32, k. 53.

42 Ibidem.

${ }^{43}$ Ibidem, k. 51.

${ }^{44}$ Ibidem, k. 56-57.
} 
Doktor wskazał, że pojedyncza sekcja trwa około 90 minut, a także, że ze względu na wysokie o tej porze roku temperatury konieczne jest rozpoczęcie badań jak najszybciej. Stanisław Łaguna wskazał też listę nazwisk lekarzy, którzy dzięki swojej wiedzy i doświadczeniu mogliby znacznie przyspieszyć prace komisji. Informacje o rozpoczęciu prac badawczych w formie zaproszenia do udziału w badaniach przesłano do sześciu poznańskich medyków, w tym do prof. Ludwika Skubiszewskiego ${ }^{45}$. Ponadto poinformowani zostali przedstawiciele prasy, komendanta PUBP ${ }^{46}$, a także zarząd gminy Żabikowo.

Dnia 23 maja 1945 r. odbyło się kolejne zebranie, na którym stwierdzono, że działania przygotowawcze zostały wykonane, a jedyny problem stanowi skąpa ilość narzędzi sekcyjnych i medycznych. Ustalono, że prace rozpoczną się 28 maja 1945 r., a o godzinie 6:00 tego dnia pod szpital miejski przy ul. Szkolnej w Poznaniu podstawiony zostanie autobus ${ }^{47}$. Do Żabikowa udali się prokuratorzy W. Jonsik i S. Mojkowski, sędzia J. Rzędowski, asesor S. Lehmann, dr S. Łaguna, a także wszyscy zaproszeni lekarze. Po wskazaniu przez zarządcę cmentarza leżącego nieopodal obozu miejsca pochówku ofiar, przystąpiono do prac ekshumacyjnych. Jak się okazało, zwłoki pochowane zostały zaledwie $10 \mathrm{~cm}$ pod ziemią, zatem już po wstępnych oględzinach zauważono wystające spod gruntu części obuwia i odzieży ${ }^{48}$. W toku późniejszych prac i w oparciu o zeznania świadków ${ }^{49}$ ustalono, że w masowym grobie oznaczonym numerem 1 znajdują się szczątki 33 więźniów przetransportowanych do Żabikowa z terenu gm. Krasnosielec powiat Maków Mazowiecki ${ }^{50}$. Komisja zgłosiła odkrycie do Zarządu Gminnego Urzędu Stanu Cywilnego ${ }^{51}$, prosząc o wystawienie dokumentów zgonów oraz poinformowanie rodzin.

Równocześnie z kolejnymi oględzinami obozu karno-śledczego w Żabikowie, w Warszawie tworzono zręby ogólnopolskiej komisji, która miałaby zajmować się badaniem zbrodni niemieckich popełnionych na obywatelach polskich podczas okupacji. Wobec ich niespotykanego ogromu należy uznać za zasadną inicjatywę mającą ujednolicić prace śledcze, naukowe i ekshumacyjne. Przedstawione wyżej prace, mające w znacznej mierze charakter społecznikowski, nie pozwalały na systemowe opracowywanie zagadnień, a jedynie na dość chaotyczne i wyrywkowe badanie miejsc zbrodni. Stworzenie zatem instytucji mogącej nadzorować

45 Ibidem, k. 58-63.

46 Powiatowy Urząd Bezpieczeństwa Publicznego.

${ }^{47}$ Ibidem, k. 70-71.

48 Ibidem, k. 72.

${ }^{49} \mathrm{~W}$ oparciu o zeznania świadka kwestię tę przedstawił także A. Wietrzykowski, op.cit., s. $38-40$.

${ }^{50}$ IPN GK 178/126, k. 10.

${ }^{51}$ Ibidem. 
wszystkie prace i decydować o ich kolejności - z uwagi na potrzeby prowadzonych postępowań przygotowawczych - uznać należy za niezwykle potrzebne. Dowodem na powyższe jest fakt, że Główna Komisja Badania Zbrodni Niemieckich, w zmienianej przez lata formie, funkcjonuje po dziś dzień, przyczyniając się do ujęcia i osądzenia wielu zbrodniarzy wojennych.

Początkiem istnienia wspomnianej komisji było zebranie Prezydium Krajowej Rady Narodowej (będącej quasi-parlamentem działającym przy Polskiej Partii Robotniczej), które odbyło się 29 lutego 1945 r. Na nim to gen. Michał Rola-Żymierski zaproponował powołanie specjalnej komisji do badania zbrodni niemieckich popełnionych na obywatelach polskich w czasie II wojny światowej ${ }^{52}$, na wzór już działających w Majdanku ${ }^{53}$ i Oświęcimiu. Dnia 30 marca 1945 r. dyrektor Biura KRN pisał do Ministra Sprawiedliwości Edmunda Zalewskiego, iż to m.in. ministrowi powierzone zostało zorganizowanie Komisji ${ }^{54} .17$ maja 1945 r. stworzono regulamin Komisji, który wskazał trzy główne cele jej prac: zbieranie materiałów i prowadzenie badań dotyczących zbrodni niemieckich, nadzór nad zgromadzonymi materiałami i dokumentami, publikowanie wyników prowadzonych prac ${ }^{55}$. Regulamin przewidywał dla Komisji Biuro, a także Prezydium, którego członkami byli Minister Sprawiedliwości i Minister Spraw Zagranicznych. Faktyczne powołanie Komisji aktem prawnym nastąpiło jednak dopiero 10 listopada 1945 r., kiedy to Tymczasowy Rząd Jedności Narodowej wydał dekret o Głównej Komisji i Okręgowych Komisjach Badania Zbrodni Niemieckich w Polsce ${ }^{56}$. Przejściowość i pewien bałagan organizacyjny do czasu wydania aktu normatywnego dobrze oddają słowa dyrektora naczelnego Alfreda Fiderkiewicza, wypowiedziane 5 lipca 1945 r. na spotkaniu Prezydium Komisji: „dotychczas nie został jeszcze ogłoszony dekret o utworzeniu Głównej Komisji Badania Zbrodni Niemieckich w Polsce, która wobec tego z formalno-prawnego punktu widzenia jeszcze nie istnieje" ${ }^{57}$.

Dekret ogłoszony został w Dzienniku Ustaw 27 listopada 1945 r. i zgodnie $\mathrm{z}$ art. 11 wszedł w życie z dniem ogłoszenia. Wspomniany akt normatywny mający moc ustawy, ale wydawany przez organ władzy wykonawczej, w kwestiach kluczowych, takich jak zadania czy organizacja Głównej Komisji, okazał się być

${ }^{52}$ AAN, KRN, sygn. 240, s. 29.

${ }^{53}$ Bruliony protokołów Polsko-Radzieckiej Komisji Badania Zbrodni, popełnionych na Majdanku, Archiwum Okręgowej Komisji Badania Zbrodni Hitlerowskich w Lublinie sygn. IPN Lu 194.

${ }^{54}$ Ibidem.

${ }^{55}$ AAN KRN, sygn. 240 s. 1314 (drugi egzemplarz), s. 33-34 (pierwszy egzemplarz).

${ }^{56}$ Dz.U. z 1945 r. nr 51, poz. 293, IPN BU 737/2.

57 AGK, GK, sygn. 123, k. 8-9, za: M. Motas (oprac.), Główna Komisja Badania Zbrodni Niemieckich w Polsce i jej oddziały terenowe w 1945 roku. Wybór dokumentów, Warszawa 1995, s. $33-34$. 
bardzo zbliżony do regulaminu stworzonego wiosną 1945 r. Zaznaczyć należy, że fakt zastosowania aktu normatywnego niebędącego ustawą związany jest z przejściowym okresem w państwie, w którym nie funkcjonował parlament. Wybory do Sejmu (Izba wyższa parlamentu została zlikwidowana) odbyły się dopiero w $1947 \mathrm{r}$.

Z art. 2 Dekretu: ,przewodniczącym Głównej Komisji jest Minister Sprawiedliwości, który powołuje członków Głównej Komisji oraz przewodniczących Okręgowych Komisji. Członków Okręgowej Komisji powołuje przewodniczący Okręgowej Komisji" ${ }^{58}$, wnioskować należy, że nowe polskie władze traktowały sprawę ścigania zbrodniarzy wojennych bardzo poważnie. Przewodniczącym Głównej Komisji został bowiem Minister Sprawiedliwości, uczestniczący przecież w zebraniach rządu. Rozwiązanie to pozwoliło na maksymalne skrócenie drogi decyzyjnej od najwyższych władz państwowych do Głównej Komisji, a tym samym musiało przełożyć się na zacieśnienie i usprawnienie współpracy w triadzie rząd - prokuratura - Główna Komisja. Nie można pominąć też faktu, że Główna Komisja przez swego przewodniczącego miała głos na zebraniach rady ministrów, co z pewnością ułatwiło wiele aspektów jej funkcjonowania, tak prozaicznych, jak choćby wielkość budżetu. Ważnym czynnikiem ułatwiającym i systematyzującym prace członkom Głównej Komisji, w tym prokuratorom, było powołanie Komisji Okręgowych. Specyfika terenowa, związana także z hitlerowskim jeszcze podziałem administracyjnym ${ }^{59}$, tworzyła uzasadnioną podstawę do tworzenia mniejszych jednostek.

Zespolenie prac, a także wyznaczenie przejrzystej podległości służbowej, spowodowało, że wymiar sprawiedliwości w zakresie osądzania omawianych zbrodni hitlerowskich funkcjonował bardzo sprawnie.

Uwagę zwraca nadzór nad pracami wykonywanymi przez Główną Komisję, który mógł zostać pogłębiony przez dalszą treść art. 2 Dekretu: „Minister Bezpieczeństwa Publicznego może delegować do Głównej Komisji i do Okręgowych Komisji przedstawicieli władz bezpieczeństwa celem współdziałania" ${ }^{0}$. Zła sława, jaką owiane jest wskazane w art. 2 ministerstwo, nie jest przedmiotem rozważań niniejszej pracy, jednak wskazać należy, że jego zadaniem było przede wszystkim zwalczanie opozycji i siłowe wprowadzanie systemu komunistycznego w Polsce. Jako wadę Dekretu o Głównej Komisji trzeba zatem wskazać możliwy nadzór bezpieki, która swym aparatem przymusu mogła wpływać na prowadzone przez Główną Komisję prace. Już pobieżna znajomość historii i historii prawa w Polsce

\footnotetext{
58 Dz.U. z 1945 r. nr 51, poz. 293, IPN BU 737/2.

59 Autor ma tu na myśli przede wszystkim podział ziem II RP na Kraj Warty i Generalną Gubernię.

${ }^{60}$ Dz.U. z 1945 r. nr 51, poz. 293, IPN BU 737/2.
} 
lat 1944-1990 pozwana dostrzec, że Ministerstwo Bezpieczeństwa Publicznego miało nadzór nad wieloma instytucjami państwa. Jednak mimo że nie zachowały się w archiwach Głównej Komisji dowody na zainteresowanie jej pracami przez bezpiekę, to nie można wykluczyć sporadycznych nacisków na pracowników Głównej Komisji. Na marginesie warto też zwrócić uwagę, że przepis sformułowany został w ten sposób, że decyzja o ewentualnym delegowaniu pracownika bezpieki zależna była tylko od woli właściwego ministra.

Art. 3 Dekretu następująco określił zadania Głównej Komisji:

a) Badanie i zbieranie materiałów dotyczących zbrodni niemieckich, popełnionych w latach 1939-1945 w Polsce lub poza jej granicami w stosunku do obywateli polskich lub osób narodowości polskiej oraz w stosunku do cudzoziemców, którzy w tym czasie przebywali w Polsce,

b) kierownictwo i uzgadnianie prac Okręgowych Komisji oraz wszystkich instytucji o pokrewnym zakresie działania i współpraca z Instytutem Pamięci Narodowej przy Prezydium Rady Ministrów,

c) ogłaszanie materiałów i wyników badań dotyczących zbrodni niemieckich i rozpowszechnianie ich w kraju i za granicą oraz udostępnianie materiałów pokrewnym instytucjom zagranicznym ${ }^{61}$.

Lit. a) art. 3 wyraźnie określa maksymalnie szeroką właściwość rzeczową i miejscową działalności Głównej Komisji, gdyż obejmuje wszystkie narodowości mieszkające w granicach II RP. Ma to z pewnością swoje uzasadnienie, zwłaszcza w przypadku badania i ścigania zbrodni popełnionych na ludności żydowskiej, a także przestępstw dokonanych na polskich obywatelach poza przedwojennymi granicami Rzeczypospolitej, co połączyć należy z zagadnieniem pracy przymusowej na terenie III Rzeszy. Pozostałe litery artykułu odnoszą się do pracy naukowej - współpraca z Instytutem Pamięci Narodowej, funkcjonującym w latach 1945-1949, a następnie od 1984 po dziś dzień, a także informacyjno-popularyzatorskiej. Ten ostatni aspekt może wydawać się najmniej istotny, ale w rzeczywistości tak nie jest. By to zrozumieć, należy rozważyć przede wszystkim ogrom zbrodni hitlerowskich popełnionych na ziemiach polskich oraz na katastrofalną sytuację materialną i demograficzną. Wynikająca z powyższego szczupłość kadr musiała zostać wsparta czynnikiem społecznym. By dotrzeć do wszystkich miejsc zbrodni, by uzyskać dowody, w tym zeznania świadków, konieczna była przychylność szukających przecież elementarnej sprawiedliwości obywateli. Zatem zwrócenie się do społeczeństwa i informowanie go o pracach Głównej Komisji mogło wpłynąć na efektywność prowadzonych postępowań i badań jedynie pozytywnie. Lit. c) art. 3 Dekretu z 10 listopada 1945 r. nakładała też na Główną 
Komisję inny ważny obowiązek: ,udostępniania materiałów pokrewnym instytucjom zagranicznym" ${ }^{2}$. Jak pisze Dorota Koczwańska-Kalita:

Zakres działalności Głównej Komisji obejmował zadania badawcze, dotyczące ekstradycji oraz historyczno-propagandowe. Pozyskiwane przez nią dokumenty, zarówno w kraju jak i za granicą, były cennym materiałem dowodowym w prowadzonych dochodzeniach, mających na celu ustalenie i wyjaśnienie okoliczności dokonanych zbrodni. Wykonywane czynności stanowiły też pomoc prawną dla zagranicznych instytucji takich jak Międzynarodowy Trybunał Wojskowy w Norymberdze, czy Komisja Narodów Zjednoczonych ds. Zbrodni Wojennych (UNWCC) w Londynie. Zgromadzone dowody były wykorzystywane podczas procesów czołowych zbrodniarzy niemieckich, jakie rozpoczynały się w Polsce i za granicą ${ }^{63}$.

Z powyższego wynika zatem, że działalność Głównej Komisji przyczyniała się także do śledztw prowadzonych przez zagraniczne wymiary sprawiedliwości. Jeden z najważniejszych artykułów Dekretu, który nie miał swego odzwierciedlenia we wcześniejszym regulaminie, oznaczony został numerem 4 i otrzymał brzmienie:

Główna Komisja i Okręgowe Komisje oraz delegowane przez nie organy mają prawo prowadzenia dochodzeń oraz badania świadków i stosują odpowiednio przepisy kodeksu postępowania karnego. Przy wykonywaniu tych czynności korzystają z uprawnień władz sądowych. Czynności podjęte przez członków Głównej Komisji i Okręgowych Komisji, posiadających kwalifikacje sędziowskie lub prokuratorskie mają moc czynności sądowych, a protokoły moc protokołów sądowych ${ }^{64}$.

W ten sposób Komisja Główna i Komisje Oddziałowe wyposażone zostały w narzędzia pozwalające zarówno na badanie zbrodni, jak i prowadzenie postępowań przygotowawczych w myśl Kodeksu postępowania karnego, który 1 lipca 1929 r. wszedł w życie rozporządzeniem Prezydenta Polski Ignacego Mościckiego z 19 marca 1928 r. ${ }^{65}$ Z powyższego wynika, że prokurator będący członkiem Głównej Komisji, oddelegowany do prac związanych ze ściganiem zbrodni prawa międzynarodowego, otrzymał zaplecze techniczne, ale też naukowe, celem sprawniejszego wykonywania powierzonych mu obowiązków. Rozwiązanie to, które określić należy jako niezwykle trafne, okazało się skutecznym narzędziem w rękach prokuratorów, dzięki któremu dowody zbierane były w sposób fachowy i systemowy.

Kolejne artykuły, których łącznie jest 11, wskazują na możliwość żądania przez członków Głównej Komisji pomocy ze strony władz lokalnych, w tym mi-

\footnotetext{
${ }^{62}$ Ibidem.

${ }^{63}$ D. Koczwańska-Kalita, (Nie) chciane dziecko III RP, Kraków 2015, s. 57-58.

${ }^{64}$ Ibidem.

${ }^{65}$ Dz.U. z 1928 r. nr 33, poz. 313.
} 
licji, oraz zobowiązują każdą osobę posiadającą dowody popełnienia zbrodni do ich ujawnienia.

Zanim jednak wydany został Dekret z 10 listopada 1945 r., w wielu miastach wojewódzkich, w tym także w Poznaniu, prace ekshumacyjne, badawcze i śledcze były już prowadzone, czego przykładem jest badanie zbrodni w obozie karno-śledczym w Żabikowie. Niemniej istnienie Głównej Komisji Badania Zbrodni Niemieckich w Polsce zachęciło lokalnych działaczy do nawiązania współpracy z centralą. Dnia 4 lipca 1945 r. temat ten podjęty został przez Polski Związek Zachodni, który nazajutrz wysłał swojego przedstawiciela do Warszawy, aby potwierdzić gotowość poznańskich społeczników do rozpoczęcia prac, a także uzyskać odpowiednie instrukcje i środki. 5 i 7 lipca 1945 r. odbyły się w Warszawie spotkania z sekretarzem Prezydium Komisji Jerzym Kornackim oraz przewodniczącym KRN Bolesławem Bierutem, w którym to spotkaniu uczestniczyli także przedstawiciele innych polskich miast. 10 lipca 1945 r., już w Poznaniu, odbyło się zebranie organizacyjne Oddziału Głównej Komisji Badania Zbrodni Niemieckich w Polsce, na którym omówiono wytyczne dotyczące budżetu, zadań organizacyjnych, prezydium i komórek powiatowych. Siedzibą oddziału Komisji stało się prywatne mieszkanie jednego z członków Komisji Józefa Szymańskiego na poznańskim Grunwaldzie, przy ul. Niecałej $14 \mathrm{~m}$. 8. Druga siedziba znajdowała się w pokojach należących do Prokuratury Sądu Specjalnego Karnego przy ul. Młyńskiej ${ }^{16}$. Powstanie poznańskiego Oddziału Komisji odnotowała też prasa. „Głos Wielkopolski” donosił, że „w celu ujednolicenia i usprawnienia zbierania dokumentów dotyczących zbrodni niemieckich istnieje Główna Komisja Badania Zbrodni Niemieckich w Polsce Oddział w Poznaniu"67.

Poznański Oddział Komisji Badania Zbrodni Niemieckich w Polsce zawiązał się po około miesiącu od majowych prac ekshumacyjnych, a w jego skład weszła część członków komisji do zbadania zbrodni niemieckich na terenie obozu w Żabikowie. W ten sposób komisja żabikowska stała się jedną z podstaw, na której oparł się poznański Oddział Komisji. Prace wykonane w maju 1945 r. kontynuowano rok później, również w maju. Należy zwrócić uwagę, że wiele nazwisk, które występują w protokołach z Żabikowa, figuruje na późniejszej liście członków Komisji Badania Zbrodni Niemieckich w Polsce. Widać to na przykładzie wyłonionego w sierpniu 1945 r. Prezydium Oddziału, w którego skład weszli kierownik - prokurator Wacław Jonsik, wojewoda poznański Feliks Widy-Wirski, dr Stanisław Łaguna, kierownik Zakładu Medycyny Sądowej oraz Czesław Pili-

${ }^{66}$ Sprawozdanie Poznańskiego Oddziału Głównej Komisji Badania Zbrodni Niemieckich w Polsce za czas od 21 czerwca 1945 do 31 lipca 1945 r., IPN GK 178/3.

${ }^{67}$ „Głos Wielkopolski”, 1 września 1945 r., nr 185, s. 3. 
chowski z PZZ. Nietrudno zatem dostrzec, że 75\% składu prezydium stanowiły osoby zaangażowane w prace w obozie karno-śledczym w Żabikowie.

Ponadto członkami Oddziału w tym czasie byli: prof. Józef Bossowski z Uniwersytetu Poznańskiego, mgr Bołądź - przedstawiciel Wojewódzkiego Urzędu Polityczno-Wychowawczego, porucznik Kaźmierski - szef Wydziału Polityczno-Wychowawczego przy Wojewódzkiej Komendzie Milicji Obywatelskiej, dr Karol Pospieszalski z Instytutu Zachodniego, ob. Siemieniewski z Wojewódzkiego Urzędu Informacji i Propagandy, ob. Zacharkiewicz - ze Związku Byłych Więźniów Politycznych i Marian Kaczmarek, sekretarz. Jedną z najważniejszych, a zarazem najaktywniejszych postaci w Oddziale był Józef Szymański, który na własny koszt zjeździł Wielkopolskę, organizując jednostki terenowe w powia$\operatorname{tach}^{68}$, co wkrótce zaczęło przynosić rezultaty w postaci podjęcia kolejnych prac nad badaniem zbrodni niemieckich ${ }^{69}$.

Oddział podzielony został według właściwości tematycznej na pięć sekcji: prawną, pod kierownictwem dr. Karola Pospieszalskiego, obozowo-więzienną (kierownictwo początkowo nieobsadzone), ekspertyz sądowych, pod kierunkiem dr. Stanisława Łaguny, i propagandową, pod kierunkiem Czesława Pilichowskiego, natomiast kwestie publikacji materiału pozostawiono prezydium ${ }^{70}$.

Poznański Oddział Komisji, zajmujący się z początku innymi miejscami kaźni polskich obywateli rozsianymi w całej Wielkopolsce, powrócił do prac w Żabikowie dopiero wiosną 1946 r., w związku ze śledztwem prowadzonym przeciwko Arthurowi Greiserowi. Ten urodzony w Środzie Wielkopolskiej (22 stycznia 1897 r.) polityk, stał się aktywnym działaczem ruchów nacjonalistycznych i antypolskich w Gdańsku, gdzie mieszkał ${ }^{71}$. Po wybuchu wojny i włączeniu Wolnego Miasta Gdańska do Rzeszy, a także po zakończeniu kampanii wrześniowej, Arthur Greiser w listopadzie 1939 r. został namiestnikiem (niem. Reichsstatthalter) Okręgu Rzeszy Poznań, (od 29 stycznia 1940 - Kraj Warty), a także naczelnikiem okręgu NSDAP (niem. Gauleiter). Rządy Arthura Greisera w Wielkopolsce i na Ziemi Łódzkiej pociągały za sobą eksterminację ludności żydowskiej, morderstwa, liczne wysiedlenia i germanizację Polaków, a zakończyły się 20 stycznia 1945 r. wraz z wycofaniem się gauleitera z Poznania przed nacierającą Armią Czerwoną.

${ }^{68}$ Sprawozdanie z działalności Komisji za rok 1945, IPN GK 162/136.

69 Jesienią 1945 r. pojawiły się w Poznaniu pierwsze protokołu posiedzeń z miast powiatowych takich jak Jarocin czy Międzychód. Patrz: IPN GK 178/2, k. 4-8.

${ }_{70}$ Protokót zebrania Wojewódzkiego Oddziału GKBZN w Poznaniu w dniu 21 sierpnia 1945 r., AGK, GK sygn. 130, k. 3-5, AGK, OK. Poznań sygn. 1, k. 11-13, M. Motas (oprac.), Główna Komisja Badania Zbrodni Niemieckich w Polsce i jej Oddziały Terenowe w 1945 r. Wybór dokumentów, s. $110-113$

${ }^{71}$ C. Epstein, Wzorcowy nazista. Arthur Greiser i okupacja Kraju Warty, Wrocław 2010, s. 25. 
W związku z podpisaniem przez stronę polską Deklaracji Moskiewskiej z 1 listopada $1943 \mathrm{r}^{72}$, polskie sądy uzyskały jurysdykcję do sądzenia osób, które dopuściły się zbrodni wojennych na terytorium RP, z wyjątkiem tzw. przestępców głównych ${ }^{73}$. Zatem Arthur Greiser sądzony miał być w kraju, który ucierpiał z powodu jego działalności. W związku z aresztowaniem 16 maja 1945 r. przez żołnierzy 242 pułku piechoty, 42 Dywizji Piechoty armii amerykańskiej ${ }^{74}$ i dzięki zabiegom Polskiej Misji Wojskowej były gauleiter Kraju Warty trafił do Warszawy, o czym donosiła prasa ${ }^{75}$. Po ponad dwóch miesiącach od lądowania w Warszawie, 13 czerwca 1946 r. Arthur Greiser, zgodnie z żądaniem mieszkańców Poznania $^{76}$, przewieziony został do stolicy Wielkopolski i osadzony w więzieniu przy ul. Młyńskiej.

Mimo postanowień Deklaracji Moskiewskiej, zgodnie z którą , pozostali przestępcy wojenni” (w odróżnieniu od „głównych”), trafiać mieli do kraju, na terenie którego podejrzany miał popełnić zbrodnię, strona zainteresowana musiała przedstawić zebrany materiał dowodowy, stanowiący podstawę ewentualnej ekstradycji. Zatem przekazanie Arthura Greisera stronie polskiej poprzedzone zostało licznymi działaniami specjalnie powołanej do tego Misji Wojskowej. Przekazanie pojmanego podejrzanego wymagało od rządu kraju, w którym sądzony miał być oskarżony, sprostania wysokim wymaganiom stawianym przez państwa okupujące terytorium Niemiec, w tym pokonania zawiłej procedury biurokratycznej. Właśnie z tego powodu rozkazem nr 29 Ministerstwo Obrony Narodowej powołało Wojskową Misję Badania Zbrodni Wojennych w Europie. W pkt. 2 rozkazu wskazano:

Nadzór nad działaniem Misji sprawowała Główna Komisja Badania Zbrodni Niemieckich, do której legacja wojskowa w strefach okupacyjnych Niemiec otrzymywała instrukcje bezpośrednio lub w formie wiążących dyrektyw delegata rządu do UN War Crimes Commission ${ }^{77}$.

${ }^{72}$ Pełny tekst Deklaracji Moskiewskiej w: T. Cyprian, J. Sawicki, Prawo Norymberskie - bilans i perspektywy, Warszawa 1948, s. 101.

${ }^{73}$ Pojęcia te szerzej omówił, a także doprecyzował A. Klafkowski pisząc: „Przy założeniu, że »główni« zbrodniarze wojenni zostali zestawieni na specjalnych listach czterech wielkich mocarstw - wszyscy pozostali zbrodniarze wojenni stanowią drugą kategorię, czyli »innych« zbrodniarzy wojennych"; zob.: A. Klafkowski, Ściganie zbrodniarzy wojennych w Niemieckiej Republice Federalnej w świetle prawa międzynarodowego, Poznań 1968, s. 102-110.

${ }^{74}$ C. Epstain, op.cit., s. 305.

75 Graiser wydany władzom polskim, „Głos Wielkopolski”, 15 marca 1946 r., Zbrodnicza trójka z Greiserem na czele już jedzie do Polski, „Głos Wielkopolski”, 28 marca 1946 r., Greiser i Fisher sprowadzeni do Warszawy, „Rzeczpospolita”, 1 kwietnia $1946 \mathrm{r}$.

${ }^{76}$ Społeczeństwo potępia mowę Churchilla i domaga się sądzenia Greisera w Poznaniu, „Głos Wielkopolski”, 1 kwietnia $1946 \mathrm{r}$.

77 IPN GK 162/286, k. 192. 
Jak pokazała praktyka, ta podwójna zależność okazała się uciążliwa, a Misja stała się de facto ekspozyturą zagraniczną Głównej Komisji Badania Zbrodni Niemieckich w Polsce ${ }^{78}$.

Rząd polski, aby zyskać jak największą skuteczność w ściganiu zbrodniarzy hitlerowskich, stworzył zatem osobną komórkę odpowiedzialną za składanie wniosków ekstradycyjnych do władz czterech państw okupacyjnych. Należy przy tym zwrócić uwagę, że osoby odpowiedzialne za popełnienie najcięższych przestępstw na terenie Generalnej Guberni czy Kraju Warty wycofywały się w głąb Niemiec przed nadciągającą Armią Czerwoną, najliczniej i najchętniej uciekając do amerykańskiej strefy okupacyjnej. Istotne jest, że podstawę do składania wniosków ekstradycyjnych stanowiły dokumenty zebrane i przygotowane przez Komisję Główną i Komisje Oddziałowe Badania Zbrodni Niemieckich w Polsce. Bez wątpienia to dzięki pracy jej członków, a także ochotników, udało się postawić przed polskimi sądami wielu zbrodniarzy, takich jak Arthur Greiser. Obowiązki Głównej Komisji sprowadzające się pierwotnie do prowadzenia prac badawczych i ścigania zbrodniarzy wojennych, zostały rozszerzone o sporządzanie wniosków ekstradycyjnych. Sposób ich przeprowadzania tak opisał Leszek Kubicki:

\begin{abstract}
Ukształtował się w praktyce następujący tryb załatwiania wniosków ekstradycyjnych z załączeniem wstępnego dowodu winy: po skontrolowaniu skargi i jej zatwierdzeniu przez Komisję, kierowano ją do Centralnego Rejestru Poszukiwanych Przestępców Wojennych w Paryżu (CROWCOS); aprobata skargi przez Komisję Zjednoczonych Narodów miała wagę wiążącego listu gończego oraz stanowiła wystarczającą podstawę do uzyskania, w razie ujęcia sprawcy, decyzji o jego ekstradycji, w razie zbiegu wniosków ze strony kilku państw o pierwszeństwie jednego z państw ubiegających się decydował dyrektoriat prawny Sojuszniczej Rady Kontroli ${ }^{79}$.
\end{abstract}

Ponadto w pkt. 4 rozkazu nr 29 wskazano: „koszty związane z wyjazdem Misji, dietami, jej pracą dochodzeniową i biurowo-techniczną ciążą na budżecie Głównej Komisji do Badań Zbrodni Niemieckich"\$0. Przez cały czas istnienia Misji, a więc do roku 1951, mimo że współpraca pomiędzy władzami zachodnich stref okupacyjnych i Polski zamarła na dobre w 1949 r. (ze stroną amerykańską już w 1947 r.), a ograniczana była jeszcze wcześniej, z wpisanych na międzynarodową listę przestępców wojennych zostało 7405 nazwisk. Najważniejsze jednak, że spośród nich 1803 osoby $^{81}$ osądzono przed polskimi sądami ${ }^{82}$.

${ }^{78}$ L. Gondek, Polskie Misje Wojskowe 1945-1949 r., Warszawa 1981, s. 32-33.

${ }^{79}$ L. Kubicki, Zbrodnie wojenne w świetle prawa polskiego, Warszawa 1963 r., s. 53-54.

${ }^{80}$ IPN GK 162/286, k. 192.

${ }^{81} 1325 \mathrm{w}$ strefie amerykańskiej, $392 \mathrm{w}$ brytyjskiej, $51 \mathrm{w}$ radzieckiej 51 i 35 we francuskiej.

${ }^{82}$ Cz. Pilichowski, Trybunat Norymberski i zasady norymberskie, a sprawa ścigania i karania hitlerowskich zbrodniarzy wojennych w latach 1945-1971, Warszawa 1971, s. 7. 
Jednoznaczna ocena działalności Misji nastręcza poważnych trudności ze względu na wyjątkową obfitość wpływających na to czynników. Jako ograniczające, a w konsekwencji negatywne, wymienić trzeba przede wszystkim postępującą niechęć strony amerykańskiej do współpracy, co powodowane było rozwijaniem się konfliktu na linii USA-ZSRR, określanym później jako „zimna wojna”. Autor w tym zjawisku upatruje najpoważniejszej przyczyny pozostawienia bez rozpoznania lub oddalenia wniosków o ekstradycję w liczbie 5 602. Analiza dokumentów, które pozostały po działalności Misji ${ }^{83}$, wskazuje na ogrom pracy, który został wykonany przez jej pracowników. Co ciekawe, wydaje się, że niewłaściwe byłoby wskazywanie na szczupłość kadr, gdyż w szczytowym momencie wszystkie polskie misje w Niemczech zatrudniały 125 osób $^{84}$. Oczywiście tylko część z nich pracowała w Misji Wojskowej Badania Zbrodni Wojennych w Europie, a liczba ta była dość zmienna, jednak wydaje się rozsądne założenie stałej pracy od kilku do kilkunastu osób. Misja, podobnie jak inne polskie instytucje okresu powojennego, borykała się z poważnymi trudnościami natury materialnej, jednak czynnikiem utrudniającym pracę był także pewien chaos decyzyjny. Z jednej strony, Misja podlegała Głównej Komisji, która w Dekrecie z 10 listopada 1945 r. nie została umocowana do sprawowania nad nią nadzoru, z drugiej strony, zależna była też od Polskiej Misji Wojskowej w Niemczech przy Sojuszniczej Radzie Kontroli Niemiec. Co więcej, sytuacja ta zmieniała się, czego podstawą były jedynie rozkazy Ministra Obrony Narodowej ${ }^{85}$. Mimo tych trudności, pracę Misji Wojskowej Badania Zbrodni Wojennych w Europie określić należy jako bardzo wartościową i zakończoną sporym sukcesem, zwłaszcza w obliczu poważnych trudności, w tym szczególnie postępującej niechęci do współpracy ze strony zachodnich mocarstw.

Równocześnie z czynnościami związanymi z ekstradycją wszczęte zostało śledztwo prowadzone przez prokuraturę przy Najwyższym Trybunale Narodowym $^{86}$, przed którym stanąć miał Arthur Greiser. Ten sąd specjalny, powstały zgodnie z Dekretem podpisanym przez Prezydenta Krajowej Rady Narodowej Bolesława Bieruta ${ }^{87}$, kontrasygnowanym przez Prezesa Rady Ministrów Edwarda Osóbkę-Morawskiego, Ministra Sprawiedliwości Henryka Świątkowskiego i Ministra Bezpieczeństwa Publicznego Stanisława Radkiewicza, powołany został do

83 Dokumenty te znajdują się w Instytucie Pamięci Narodowej, pod spisem IPN GK 162.

${ }^{84}$ J.A. Radomski, Misje wojskowe na Zachodzie z ramienia komunistycznych władz z Polski i ich zadania 1945-1948, [w:] R. Majzner (red.), Si vis pacem, para bellum. Bezpieczeństwo i polityka Polski. Ksiega jubileuszowa ofiarowana profesorowi Tadeuszowi Dubickiemu, Włocławek - Częstochowa 2013, s. 423.

${ }^{85}$ IPN GK 162/286, k. 189190.

${ }^{86}$ Dz.U. z 1946 r. nr 5, poz. 45.

${ }^{87}$ Ibidem. 
sądzenia „zbrodni o najwyższym wymiarze gatunkowym" ". Za niezwykle celne uznać należy porównanie Tadeusza Cypriana i Jerzego Sawickiego, którzy stwierdzili, że:

Proces norymberski, rozpoczęty 20 listopada 1945 r. toczył się przed Trybunałem o najwyższym autorytecie prawniczym i międzynarodowym. Odpowiednikiem niejako tego Trybunału dla spraw o znaczeniu krajowym miał być w Polsce Najwyższy Trybunał Narodowy ${ }^{89}$.

Dekret o NTN ogłoszony został 22 stycznia 1946 r. i wszedł w życie tego samego dnia. Jego pierwszym podsądnym był Arthur Greiser, którego proces odbył się w Poznaniu. Wraz z sądem specjalnym powołana została prokuratura Najwyższego Trybunału Narodowego, współpracująca od początku z Główną Komisją.

Powołanie NTN uznać należy za potrzebne z uwagi na doniosłość prowadzonych przed nim spraw. Została ona podkreślona przez obsadę składów sędziowskich i prokuratorów, rekrutujących się spośród najwybitniejszych polskich prawników, którym udało się przeżyć wojnę. Trybunał nie miał swojej stałej siedziby, a jego istnienie $\mathrm{w}$ domyśle pozostawało jedynie czasowym. Przykład doniosłości i także zasadności powołania NTN obrazuje proces Arthura Greisera, który odbył się w największej poznańskiej, niezniszczonej działaniami wojennymi, sali - auli uniwersyteckiej. Dzięki temu rozprawa dostępna była dla szerokiej publiczności żywo zainteresowanej końcowym rozstrzygnięciem. Oczywiście można podejrzewać polskie władze komunistyczne o celowe działanie propagandowe, jednak należy pamiętać, że lokalna społeczność miała silną potrzebę zaspokojenia poczucia sprawiedliwości. Lata okupacji okazały się dla mieszkańców Poznania wyjątkowo trudne, a co ważniejsze, wielu przyniosły śmierć najbliższych czy wysiedlenia. Sądzenia Arthura Greisera przed sądem powszechnym, w jednej z kilkudziesięciu podobnych sal, bez specjalnego prostego trybu, miejscowi mieszkańcy mogliby nie zrozumieć.

Mimo niewątpliwie pozytywnej oceny prac Najwyższego Trybunału Narodowego, dekret (z późniejszymi zmianami), który go ustanowił, zawierał kilka poważnych wad. Za sprzeczną z dzisiejszymi zasadami praworządności i demokracji uznać należy jednoinstancyjność. Brak możliwości zaskarżenia wyroku w tak doniosłej materii i przy częstych rozstrzygnięciach skazujących na karę śmierci (jak w przypadku Arthura Greisera) czy kary dożywotniego pozbawienia wolności, uznać należy za poważny błąd ustawodawcy, mimo że upraszczał on procedurę i czas trwania procesu do stopnia prawdopodobnie zrozumiałego nawet

${ }^{88}$ J. Gumkowski, T. Kułakowski, Zbrodniarze hitlerowscy przed Najwyższym Trybunałem Narodowym, Warszawa 1967, s. VI.

${ }^{89}$ T. Cyprian, J. Sawicki, Siedem procesów przed Najwyższym Trybunatem Narodowym, Poznań 1962, s. X. 
dla laików obserwujących rozprawę. Pozór dwuinstancyjności stanowiło jedynie prawo łaski jako prerogatywa prezydenta KRN. Należy w tym miejscu wskazać, że przyznana ona została zwierzchnikowi jednego z organów Polskiej Partii Robotniczej, mieniącym się jedynie polskim quasi-parlamentem. Pomijając jednak fakt sprzeczności z obowiązującą w owym czasie Konstytucją kwietniową, zwrócenie się do prezydenta KRN i ewentualne zastosowanie prawa łaski, nie rozstrzygało o winie skazanego, a jedynie o zwolnieniu z odbycia czy wykonania kary.

Skład sędziowski, zgodnie z Dekretem, rozszerzony został o czynnik społeczny, co uznać z pewnością należy za pozytywne i aprobowane także w dzisiejszych procedurach karnych krajów demokratycznych, jednakże także w tej kwestii dostrzec należy poważną wadę. Ławnikami pozostać mogli tylko członkowie Krajowej Rady Narodowej ${ }^{90}$, a zatem działacze komunistyczni. Dobranie członków składu sędziowskiego (ławników) tylko z jednej grupy politycznej ponieważ opiera się na ludziach o podobnych przekonaniach, stanowi w istocie zaprzeczenie uwzględnienia czynnika społecznego. Jednym z wyznawanych przez tę grupę poglądów jest wrogość wobec ruchów prawicowych, zwłaszcza tych skrajnych, jak faszyzm i nazizm. Zatem taki przepis mógł wywołać podejrzenie co do braku obiektywizmu ławników.

Warte uwagi jest też rozwiązanie dotyczące składu sędziowskiego, zgodnie z którym sędziowie zawodowi mieli mieć jedynie „kwalifikacje sędziowskie”, co, jak pokazała praktyka, nie był to tożsame z prawem wykonywania zawodu w związku z odbytą aplikacją. Podobna sytuacja miała miejsce w prokuraturze NTN. Rozwiązanie to teoretycznie mogło negatywnie wpłynąć na jakość pracy Trybunału, a także jego orzeczeń, a jednak, jak wspomniano wyżej, członkami NTN i jego prokuratury byli wybitni polscy prawnicy, choć w części nieposiadający uprawnień zawodowych sędziego czy prokuratora ${ }^{91}$.

Oczywistym błędem - niedopatrzeniem legislacyjnym był też brak możliwości odwołania prokuratora, sędziego i ławnika, co jednak zostało zmienione już pierwszą nowelizacją Dekretu ${ }^{92}$.

Najwyższy Trybunał Narodowy, zgodnie z Dekretem z 22 stycznia 1946 r., był właściwy do rozpoznawania kasacji prokuratorskich od wyroków sądów specjalnych. Istotnym rozwiązaniem prawnym był też nadzór nad tymi ostatnimi. W ten sposób NTN miał prawdopodobnie stać się, poprzez możliwość rozpoznawania nadzwyczajnych środków zaskarżenia, jednym z elementów całego procesu, którego głównym celem była rozprawa z opozycją, czym w znacznej mierze zajmowały się sądy specjalne. Praktyka jednak nie ujawniła przypadków rozpo-

\footnotetext{
${ }^{90}$ Art. 5; Dz.U. z 1946 r. nr 5, poz. 45.

${ }^{91}$ Art. 2 i 3, ibidem.

${ }_{92}$ Dz.U. z 1946 r., nr 59 poz. 325, art. 6.
} 
znawania skarg przez Trybunał, co skutkowało pozbawieniem go tej prerogatywy już podczas pierwszej nowelizacji ${ }^{93}$.

Pochylając się nad zagadnieniem dotyczącym właściwości Najwyższego Trybunału Narodowego, wskazać należy, że obejmowała ona dwa akty prawne: Deklarację Moskiewską i Dekret z 22 stycznia 1946 r. ${ }^{94}$ „o odpowiedzialności za klęskę wrześniową i faszyzację życia państwowego". Wobec powyższego przed Trybunałem stanąć mogli także obywatele Polsce, odpowiedzialni za przegraną kampanię wrześniową i faszyzację (co w nowomowie władz komunistycznych równoznaczne było ze sprawowaniem autorytarnych rządów przez sanację) życia publicznego. Wyobrazić można sobie zatem, że przed NTN obok zbrodniarzy hitlerowskich postawieni zostają dowódcy kampanii wrześniowej, np. gen. Tadeusz Kutrzeba czy przedwojenny prezydent Poznania Erwin Więckowski. Do sytuacji takich nigdy jednak nie doszło, z dwóch przyczyn. Po pierwsze, najważniejsze osoby ostatnich rządów II RP często albo nie przeżyły wojny albo nie powróciły z emigracji. Drugi powód ma podstawy propagandowe: wątpliwe, by sadzanie na jednej ławie oskarżonych niemieckich zbrodniarzy i polskich polityków czy dowódców wojskowych zyskało akceptację społeczną. Zatem mimo prawnej możliwości zastosowania tego rozwiązania Najwyższy Trybunał Narodowy w praktyce sądził jedynie zbrodniarzy nazistowskich ${ }^{95}$.

Z perspektywy ponad siedemdziesięciu lat od czasu zakończenia ostatniego procesu przed Najwyższym Trybunałem Narodowym, ideę jego powstania oraz samą pracę należy ocenić pozytywnie. W siedmiu procesach przed NTN stanęło 49 osób, z czego 31 skazano na karę śmierci ${ }^{96}, 17$ na kary pozbawienia wolności, a jedną osobę uniewinniono. Po upływie tak wielu lat i przeprowadzeniu szeregu badań przez historyków, nie ulega wątpliwości, że osoby skazane na najwyższy wymiar kary, takie jak Arthur Greiser, Rudolf Höß, Amon Göth, Albert Forster, były winne zarzucanych im czynów i dziś określane są mianem zbrodniarzy. $\mathrm{Na}$ uwagę zasługuje też podobieństwo do funkcjonowania Międzynarodowego Trybunału Wojskowego i linii orzeczniczej określanej później jako „zasady norymberskie".

${ }^{93}$ Dekret z dnia 17 października 1946 r. o zmianie dekretu z dnia 22 stycznia 1946 r. o Najwyższym Trybunale Narodowym (Dz.U. z 1946 r. nr 59, poz. 325).

${ }^{94}$ Dz.U. z 1946 r., nr 5, poz. 45.

${ }_{95}$ Oprócz Arthura Greisera byli to: Amon Göth, Ludwig Fischer, Ludwig Leist, Josef Meisinger, Max Daume, Rudolf Höß, Albert Forster, Josef Bühler i 40 członków załogi obozu w Oświęcimiu.

${ }^{96}$ Autor pominął rozważania dotyczące zasadności stosowania kary śmierci, jako po pierwsze niezwiązane z tematem pracy, a po drugie z uwagi na fakt, że sankcja ta, znajdowała się w katalogu kar, obowiązującego wówczas Kodeksu karnego. 
Aby sporządzić akt oskarżenia przeciwko Arthurowi Greiserowi, który sądzony miał być przed Najwyższym Trybunałem Narodowym, należało zbadać fakt zaistnienia oraz zakres zbrodni popełnionych przez Niemców w Wielkopolsce i na Ziemi Łódzkiej. Właśnie w tej sprawie 12 marca 1946 r. Główna Komisja Badania Zbrodni Niemieckich w Polsce zwróciła się do prokuratora Sądu Okręgowego w Poznaniu o zarządzenie w trybie art. $254 \S 1$ i $2 \mathrm{kpk}^{97}$ przeprowadzenia czynności sądowych, mających na celu m.in. wskazanie informacji dotyczących obozu karno-śledczego w Żabikowie, w tym ustalenia warunków tam panujących i liczby zamordowanych osób ${ }^{98}$. W tym samym miesiącu do Sądu Okręgowego w Poznaniu trafiły wszystkie sporządzone dotychczas materiały dotyczące obozu w Żabikowie ${ }^{99}$.

Okręgowa Komisja Badania Zbrodni Niemieckich w Polsce 7 maja 1946 r. poinformowała posterunek milicji w Żabikowie, lekarza powiatowego, Starostę Powiatowego w Poznaniu, Urząd Bezpieczeństwa Publicznego, Urząd Informacji i Propagandy oraz Polski Związek Zachodni o rozpoczęciu w dniu 11 maja 1946 r. ${ }^{100}$ prac ekshumacyjnych na cmentarzu w Żabikowie, gdzie chowano zmarłych bądź zamordowanych osadzonych. Zarządzono też, by zarząd gminny w Żabikowie przygotował niezbędne narzędzia, takie jak stoły, nosze i artykuły higieniczne, a także wskazał 12 ludzi potrzebnych do prac fizycznych ${ }^{101}$.

Dnia 11 maja 1946 r. na cmentarzu w Żabikowie, gdzie rok wcześniej dokonano ekshumacji tylko jednego z grobów masowych, stawili się wiceprokurator Alfons Lehmann, sekretarz poznańskiego Oddziału Komisji Marian Kaczmarek i dr Stanisław Łaguna, którzy przy współudziale przedstawicieli różnych służb mundurowych, a także PCK, rozpoczęli prace. W zachodniej części cmentarza odkryto dwie obszerne mogiły zbiorowe oraz trzecią mniejszą, które oznaczono numerami od 2 do 4 . Po rozpoczęciu prac ustalono, że zwłoki pochowane zostały w pośpiechu, na głębokości od 0,90 do 3 metrów pod ziemią ${ }^{102}$. Łącznie w trzech grobach znaleziono 24 ciała, które wydobyto, dokonując następnie sekcji. Następnie rodziny ofiar rozpoznały kilku swoich krewnych, natomiast pozostałe ciała pochowane zostały w tekturowych trumnach. Ustalenie personaliów osób pochowanych było utrudnione, ponieważ większość ciał została pozbawiona odzieży i zawinięta w obozowe koce.

\footnotetext{
97 Dz.U. z 1928 r. nr 33, poz. 313.

98 IPN GK 196/31, k. 10.

99 Ibidem, k. 11.

${ }^{100}$ IPN GK 178/129, k. 24.

101 Ibidem, k. 5.

102 Ibidem, k. 9.
} 
Dr S. Łaguna wraz z całym zespołem przeprowadził szczegółowe badania odkrytych zwłok ${ }^{103}$. Opisane zostały przedmioty znalezione w grobach oraz dokładny stan ciał i przyczyny śmierci. Podczas prac ekshumacyjnych wykonano bogatą dokumentację zdjęciową, którą następnie załączono do protokołu sekcyjnego. W wyniku przeprowadzonych badań ustalono, że dwa spośród 24 odkrytych ciał należą do kobiet. Jako przyczynę śmierci w przypadku siedmiu badanych zwłok wskazano rany postrzałowe w tył głowy. Jeden z więźniów stracił życie przez silne pourazowe uszkodzenie czaszki, a jeden przez dekapitację. U pozostałych 15 osób, z uwagi na silnie zaawansowany proces rozkładu ciał, nie udało się ustalić bezpośredniej przyczyny zgonu. Dr Łaguna wyraźnie jednak zaznaczył, że nie można w tym przypadku wykluczyć wycieńczenia i skrajnie trudnych warunków obozowych ${ }^{104}$.

Rezultat prac wykonanych przez poznański Oddział Komisji Badania Zbrodni Niemieckich w Polsce wykorzystali prokuratorzy Najwyższego Trybunału Narodowego do sporządzenia aktu oskarżenia, a zwłaszcza punktu C, dotyczącego działań gauleitera podczas II wojny światowej w okupowanej Polsce, w okresie od 12 września 1939 r. do stycznia 1945 r. Oskarżono w nim Arthura Greisera o naruszenie art. 43, 46, 47, 50, 52, 55, 56 konwencji haskiej ${ }^{105}$ :

naruszając zasady prawa narodów oraz postulaty ludzkości i sumienia narodów, bądź z własnej inicjatywy, bądź urzeczywistniając przestępne wskazania władz cywilnych i wojskowych Rzeszy Niemieckiej działał na szkodę Państwa Polskiego jego obywateli podżegając do dokonania, udzielania pomocy przy dokonaniu i dokonując: (...) zabójstw ludności cywilnej i jeńców, (...) znęcania się, prześladowania, niszczenia polskiej kultury, grabieży polskich wartości kulturalnych (...) bezprawnego pozbawiania ludności polskiej jej własności prywatnej ${ }^{106}$.

Oskarżano też Arthura Greisera o lżenie i wyszydzanie Narodu Polskiego ${ }^{107}$, zabójstwa przez publiczne egzekucje bądź w obozach koncentracyjnych ${ }^{108}$, za-

103 Ibidem, k. 1150.

104 Ibidem, k. 79.

${ }^{105}$ Umowy międzynarodowy z 18 października 1907 r. zawarta Hadze, która zobowiązywała państwa ja ratyfikujące do m.in. pokojowego załatwiania sporów międzynarodowych, a także określająca sposoby prowadzenia konfliktów zbrojnych. Poszczególne konwencje zostały w okresie międzywojennym ratyfikowane także przez Polskę patrz: Dz.U. z 1930 r. nr 9, poz. 64, Dz.U. z 1936 r. nr 6, poz. 64, Dz.U. z 1936 r. nr 6, poz. 65, Dz.U. z 1936 r. nr 6, poz. 66, Dz.U. z 1936 r. nr 6, poz. 67, Dz.U. z 1936 r. nr 6, poz. 68, Dz.U. z 1936 r. nr 60, poz. 439.

${ }^{106}$ Pkt. C aktu oskarżenia.

107 Czyny te zakwalifikowano jako przestępstwa zgodnie z obowiązującym wówczas Kodeksem karnym z 1932 r. (Dz.U z 1932 r. nr 60, poz. 517 z późn. zm.) z art. 152 kk Kto publicznie lży lub wyszydza Naród albo Państwo Polskie, podlega karze więzienia do lat 3 lub aresztu do lat 3.

${ }^{108}$ Czyny te zakwalifikowano jako przestępstwa z art. $225 \S 1 \mathrm{kk}$ Kto zabija człowieka, podlega karze więzienia na czas nie krótszy od lat 5 lub dożywotnio albo karze śmierci. 
bójstwa ludności żydowskiej czy tworzenie gett ${ }^{109}$. Prokuratorzy postawili też zarzuty, co szczególnie ważne w kontekście obozu w Żabikowie, brania udziału w znęcaniu się nad ludnością polską, zadawanie bardzo ciężkiego uszkodzenia ciała albo powodowanie takiegoż rozstroju zdrowia, długotrwałe pozbawianie wolności i pracę przymusową więźniów, a także o wysiedlanie całych miejscowości do Generalnej Guberni, zabieranie dzieci rodzicom, aby zerwać ich kontakt z polskością poprzez umieszczanie w niemieckich placówkach wychowawczych i nadawanie im niemieckich imion i nazwisk ${ }^{110}$.

Obszerny akt oskarżenia, obejmował także 32-stronicowe uzasadnienie, które podzielone zostało na rozdziały:

wcielenie zachodnich ziem polskich do Rzeszy Niemieckiej, wyjątkowy stan prawny dla Polaków, walka z religią, walka z polską kulturą i nauką, eksploatacja gospodarcza, wysiedlanie ludności polskiej, poniżanie godności narodowej, obozy koncentracyjne, egzekucje, zagłada ludności żydowskiej, obóz straceń Żydów w Chełmie nad Nerem, Agresja, zabór Wolnego Miasta Gdańska, pogwałcenie prawa wojennego o okupacji ${ }^{111}$.

109 Czyny te zakwalifikowano jako przestępstwa z:

art. $225 \S 1 \mathrm{kk}$,

art. $248 \S 1 \mathrm{kk}$ Kto człowieka pozbawia wolności, podlega karze więzienia do lat 5,

art. $248 \S 2$ kk Jeżeli pozbawienie wolności trwało dłużej niż 14 dni albo łączyło się ze szczególnym udręczeniem lub oddanie we władztwo obcego państwa albo w innych szczególnie ciężkich przypadkach, sprawca podlega karze więzienia do lat 10,

art. $249 \S \mathrm{kk}$ Kto powoduje oddanie innej osoby w stan niewolnictwa, kto uprawia handel niewolnikami lub bierze udział w przedsiębiorstwie, z tym związanym, podlega karze więzienia na czas nie krótszy od lat 5 ,

art. $235 \S 1 \mathrm{kk}$ Kto a) pozbawia człowieka wzroku, słuchu, mowy, zdolności płodzenia, albo b) powoduje inne trwałe kalectwo, ciężką chorobę nieuleczalną, chorobę zagrażającą życiu, albo trwałą chorobę psychiczną lub trwałą niezdolność do pracy zawodowej, podlega karze więzienia do lat 10,

art. $236 \S 1 \mathrm{kk}$ Kto powoduje a) uszkodzenie ciała lub rozstrój zdrowia, które nie zagrażają życiu lub zagrażają mu tylko chwilowo, a naruszają czynność narządu ciała co najmniej w przeciągu dni 20, albo b) trwałe zeszpecenie lub trwałe zniekształcenie ciała, podlega karze więzienia do lat 5 .

110 Czyny te zakwalifikowano jako przestępstwa z:

art. $235 \S 1 \mathrm{kk}$,

art. $236 \S 1 \mathrm{kk}$,

art. $248 \S 1 \mathrm{kk}$ Kto człowieka pozbawia wolności, podlega karze więzienia do lat 5,

art. $249 \mathrm{kk}$,

art. $246 \mathrm{kk}$ Kto znęca się fizycznie lub moralnie nad pozostającą w stałym lub przemijającym stosunku zależności od sprawcy osobą nieletnią poniżej lat 17 lub bezradną, podlega karze więzienia do lat 5 ,

art. 199 kk Kto wbrew woli osoby, mającej prawo opieki lub nadzoru, uprowadza lub zatrzymuje nieletniego poniżej 17 lat, albo osobę, znajdującą się pod opieką lub nadzorem z powodu nienormalności lub nieprzytomności podlega karze więzienia do lat 5 .

${ }^{111}$ Cały tekst aktu oskarżenia w stenogramie procesu wydanym przez Główną Komisję Badania Zbrodni Niemieckich w Polsce, Proces Arthura Greisera przed Najwyższym Trybunatem Narodowym, Warszawa 1946, Uzasadnienie, s. 15-47. 
Część uzasadnienia w rozdziale „obozy koncentracyjne” poświęcona została zbrodniom popełnionym na terenie obozu karno-śledczego w Żabikowie, które opisano w ten sposób:

Jako szczególne sposoby pozbawienia więźniów życia stosowano topienie ich w głębokim basenie oraz masakrowanie twarzy przez kilkakrotne rzucanie na twarze leżących więźniów i dobijanie ich strzałem z pistoletu ${ }^{112}$.

\section{I dalej:}

W niesłychanie brutalnych warunkach pozbawiono życia część więźniów przy ewakuacji obozu przed nadciągającą Armią Czerwoną. Do jednego z drewnianych baraków wtłoczono około 160 więźniów, m.in. chorych, niezdolnych do marszu, oblano benzyną i spalono żywcem ${ }^{113}$.

Należy w tym miejscu wskazać, że ten fragment aktu oskarżenia odnosi się bezpośrednio do ustaleń, poczynionych przez specjalną, wspomniana wcześniej komisję, która dokonywała oględzin pozostałości Obozu Karno-Śledczego w Żabikowie, wśród członków której znaleźli się S. Babski z PCK i dziennikarz Albin Wietrzykowski ${ }^{114}$.

Zbrodnie popełnione na terenie obozu karno-śledczego zakwalifikowane zostały w akcie oskarżenia przez prokuratorów jako przestępstwa $\mathrm{z}$ art. $225 \S 1 \mathrm{kk}$ $235 \S 1 \mathrm{kk}$ i $236 \S 1 \mathrm{kk}^{115}$, dotyczących zbrodni zabójstwa, doprowadzenia drugiej osoby do trwałego kalectwa bądź spowodowanie jej rozstroju zdrowia.

Dnia 21 czerwca 1946 r. prezes Sądu Apelacyjnego w Poznaniu wydał komunikat, w którym wskazał, że rozprawy odbywać się będą w niezniszczonej działaniami wojennymi Auli Uniwersyteckiej w Poznaniu. Biorąc pod uwagę spore zainteresowanie ustanowiono nawet biuro dystrybucji biletów ${ }^{116}$.

Najwyższy Trybunał Narodowy rozpoznawał swą pierwszą sprawę w następującym składzie sędziowskim: Kazimierz Bzowski - przewodniczący, Prezes Sądu Najwyższego, sędzia Emil Rappaport, sędzia Sądu Najwyższego Witold Kutzner, wiceprezes Sądu Apelacyjnego w Poznaniu Alfred Eimer, sędzia zapaso-

112 Proces Artura Greisera przed Najwyższym Trybunałem Narodowym, Główna Komisja Badania Zbrodni Niemieckich w Polsce, Warszawa 1946 r., s. 35. Wskazany fragment aktu oskarżenia oparty został na licznych i spójnych zeznaniach świadków m.in. Marty Bąbelek, Jadwigi Andrzejewskiej, Franciszka Owczarczaka i Franciszka Koniecznego, którzy złożyli zeznania przed prokuratorami Oddziałowej Komisji w Poznaniu, IPN GK 178/126, IPN GK 178/127, IPN GK 178/129.

113 Ibidem.

114 A. Wietrzykowski w swej książce pt. Zbrodnie Niemieckie w Żabikowie. Zeznania Dokumenty tematowi spalenia ok. 160 więźniów poświęcił podrozdział Ostatnia straszna noc.

115 Dz.U z 1932 r. nr 60, poz. 517 z późn. zm.

116 B. Rudawski w swym artykule pt. Proces Arthura Greisera przed Najwyższym Trybunałem Narodowym, który ukazał się w „Przeglądzie Zachodnim” 2016, nr 5, na stronie 4 umieścił fotografie imiennego biletu wstępu na rozprawę. 
wy, prezes Specjalnego Sądu Karnego w Krakowie. W składzie orzekającym znalazło się też, zgodnie z dekretem o NTN, sześciu ławników (dwóch zapasowych), którzy wyłonieni zostali spośród posłów Krajowej Rady Narodowej. Oskarżycielami Greisera zostali Pierwszy Prokurator oraz Prokuratorzy NTN Jerzy Sawicki i Mieczysław Siewierski. Na szczególną uwagę zasługuje postać Józefa Skorżyńskiego z Głównej Komisji Badania Zbrodni Niemieckich w Polsce, który prowadząc śledztwo kompletował materiały do aktu oskarżenia, także te sporządzone w związku z badaniami w Żabikowie. Obrońcami z urzędu zostali dwaj znani poznańscy adwokaci - Stanisław Hejmowski i Jan Kręglewski. Roli tej przyjąć nie chciał żaden ze wspomnianych prawników, a Hejmowski argumentował to utratą podczas wojny dwóch braci i wysiedleniem do Generalnej Guberni ${ }^{117}$.

Arthur Greiser, na co wskazywały materiały dowodowe zebrane w toku śledztwa, osobiście nie dokonał opisanych w akcie oskarżenia zbrodni przeciwko życiu. Fakt ten, a także zasłanianie się wykonywaniem rozkazów swoich przełożonych, stanowiły przez cały proces linię obrony oskarżonego. Znalazło to potwierdzenie już pierwszego dnia, kiedy w oświadczeniu oskarżony wskazał, że wiedział o istnieniu obozów i więzień, jednakże pozostałe kwestie, takie jak warunki tam panujące, tortury i egzekucje dokonywane w Chełmie nad Nerem, Forcie VII czy też w Żabikowie nie były mu znane. Oskarżyciele, przesłuchując dziesiątki osób, starali się wykazać, że Arthur Greiser dokonał którejś ze zbrodni osobiście - to się jednak nie udało.

Już w pierwszym dniu rozprawy Trybunał dopuścił dowód z przesłuchania świadków, wniesiony przez prokuratora. Ustalenia ich personaliów i przesłuchania w postępowaniu przygotowawczym dokonano przy udziale członków (prokuratorów) i pracowników Oddziałowej Komisji Badania Zbrodni Niemieckich w Poznaniu. Przesłuchiwani świadkowie, przebywający okresowo w obozie karno-śledczym w Żabikowie, opisywali warunki tam panujące, a także przypadki znęcania się nad więźniami i zabójstwa. Szczególnie wartymi odnotowania są zeznania świadka Pawła Schmidta, który za odmowę podpisania volkslisty został uwięziony w Żabikowie, gdzie był bity za to, że - jak zeznał - „za wczasu nie zdjąłem czapki przed Lagerführerem Walterem". Następnie świadek opisał karanie więźniów w ten sposób:

przyśpieszono tempo pracy, ograniczono racje żywnościowe, wydawano tylko kawę i wszyscy musieli pracować biegiem. (...) Nosiliśmy w skrzyniach piasek i żwir (...) kładziono tak wielkie ilości piasku, że nie mogliśmy roboty biegiem wykonać. Starzec, który ze mną niósł piasek, raz po raz upadał. W tym momencie dopadali SS-manni i bili nas bykowcami (...) [Jednego ze starców] nazwiskiem Kotera (...) zaczęli obijać kijami, tak że stracił przytomność. Potem starca wrzucono do otworu kloacznego ${ }^{118}$.

117 IPN GK 196/34, k. 63.

118 Proces Arthura Greisera przed Najwyższym Trybunatem Narodowym, Warszawa 1946, s. $58-59$. 
Z kolei świadek Jan Zagierski, dziennikarz z Poznania, zeznawał w procesie:

Widziałem w Żabikowie taki wypadek: dwóch młodych chłopców, jeden Rosjanin i jeden Polak leżeli na kupie piasku straszliwie zbici i kiedy myśmy szli do łaźni, rzucono ich w naszych oczach do basenu. Przypuszczam, że obaj utonęli ${ }^{119}$.

W toku procesu przeprowadzono też dowody z opinii biegłych różnych dziedzin posiadających wiadomości specjalne z zakresu historii, ekonomii czy medycyny. W przypadku ostatniej z dziedzin, biegłym został członek Głównej Komisji Badania Zbrodni Niemieckich, pracujący w oddziale poznańskim, dokonujący prac ekshumacyjnych m.in. w Żabikowie Stanisław Łaguna. Na pytanie przewodniczącego składu sędziowskiego, dotyczące sposobu traktowania więźniów w obozach, biegły wspominał m.in. o pracy przez nich wykonywanej:

Jeżeli chodzi o nadmierną pracę, to wiadome jest, że w Forcie VII i Żabikowie praca ta nie była pracą służącą dla jakiegokolwiek utylitarnego celu lecz pracą nie dającą żadnego efektu i pożytku. Było to noszenie przez przeciąg kilku lub kilkunastu godzin jakiejś belki 60-70 kilogramowej, obchodzenie z nią po nie wiem ile razy boiska albo obozu lub bezcelowe noszenie cegieł itp.

Dalej odnosząc się do pytania prokuratora dotyczącego sposobu zabijania więźniów biegły stwierdził, że:

w przypadku ofiar żabikowskich (...) rozstrzelano 33 osoby. Tam nie u wszystkich ofiar stwierdzono śmiertelne rany postrzałowe; stwierdzono np. rany postrzałowe okolicy barku, przy czym pocisk przebiegł w ten sposób, że nie zostało uszkodzone jakieś większe naczynie, które uzasadniałoby śmierć wskutek skrwawienia. Stąd na szeregu przypadków w tych grupach można na podstawie analizy dojść do wniosku, że ofiary nierzadko dostawały się do grobu jeszcze żywe ${ }^{120}$.

Pytania prokuratora dotyczyły też ogólnej ilości wykonanych ekshumacji. Biegły nie potrafił wskazać dokładnej liczby, ale oszacował ją na poziomie 6 tysięcy w samej Wielkopolsce ${ }^{121}$. Stanisław Łaguna zaznaczył też, że w toku przeprowadzonych badań odkryto wiele pustych grobów, w których czasowo znajdowały się w ciała, transportowane następnie do krematoriów. Medyk sądowy stwierdził też:

Cała Polska jak długa i szeroka, we wsiach i miastach, na odludziach i miejscach zamieszkałych pokryta jest niewątpliwie grobami, o których nikt nie wie, tym bardziej, że grzebanie przez Niemców zwłok osób pozbawionych życia, odbywało się w wielu wypadkach potajemnie ${ }^{122}$.

\footnotetext{
119 Ibidem, s. 59.

${ }^{120}$ Ibidem, s. 196-197.

121 Ibidem, s. 195.

122 Ibidem, s. 194.
} 
Prokuratorzy dopytywali też o ślady znęcania się i używania przemocy wobec więźniów, których zwłoki odnaleziono. Dr S. Łaguna stwierdził, że ślady takich działań widoczne były właściwie w każdym grobie, a ponadto na podstawie przeprowadzonych badań porównał działanie oprawców do średniowiecznych tortur $^{123}$.

Dnia 9 czerwca 1946 r. w czternastym dniu rozprawy Trybunał wydał wyrok, w którym orzekł:

Arthura Greisera uznać winnym wszystkich zbrodni zarzucanych mu przestępstw, z tym ograniczeniem, że zabójstw, uszkodzeń cielesnych i znęcań się Arthur Greiser osobiście nie dokonywał. Za powyższe przestępstwa skazać Arthura Greisera na karę śmierci, nadto orzec utratę praw publicznych i obywatelskich praw honorowych na zawsze oraz konfiskatę całego jego mienia; od ponoszenia kosztów sądowych i uiszczenia opłaty sądowej go zwolnić. Dowody rzeczowe pozostawić przy aktach sprawy ${ }^{124}$.

W uzasadnieniu wyroku wyczytać możemy, że Arthur Greiser był:

samodzielnym, ambitnym i wyrafinowanym inicjatorem i organizatorem faszystowsko-hitlerowskiego zespołu okrutnych środków, prowadzących do masowego wyniszczenia ludności miejscowej w imię całkowitej zagłady jej siły fizycznej i odporności narodowej, jako Fernziel’u (celu na dalszą przyszłość) na danym „ćwiczebnym” obszarze zniemczenia ${ }^{125}$.

W końcowej części uzasadnienia wskazał natomiast Trybunał, i to stanowi konstrukcję i podstawę uzasadniającą skazanie Arthura Greisera:

Przestępstwa, popełniane przez oskarżonego Greisera, przewidziane są - w związku z Kodeksem Karnym - w art. 1 § 1 a) dekretu z dnia 31.VIII.1944 r. (w brzmieniu znowelizowanym z dnia 16.II.1945 r.) o wymiarze kary dla faszystowsko-hitlerowskich zbrodniarzy (Dz.U. RP, poz. 29) oraz w art. $1 \S 2$ tegoż dekretu, który w art. $1 \S 1$ jako jedyną za nie sankcję, nie ulegającą zamianie na karę pozbawienia wolności przewiduje karę śmierci. W związku ze skazaniem oskarżonego Greisera na karę powyższą Najwyższy Trybunał Narodowy zastosował do niego skutki z tą karą związane na mocy art. $47 \S 1 \mathrm{a}$ i art. $52 \S 2 \mathrm{KK}$ oraz art. 5 dekretu z $31 \mathrm{VIII}$ 1944 r. (z dnia 16 II 1945 r.).

Wspomniany wyżej dekret, stanowiący kluczową podstawę prawną do ścigania przestępców wojennych, wykorzystywany także do rozprawy z opozycja, wobec przejmującej rządy w Polsce władzy komunistycznej, zaliczany jest do przepisów najdłużej obowiązujących w Polsce od roku $1944^{126}$. Kluczowy pierwszy artykuł wyposażony został w normę sankcjonującą:

123 Ibidem.

124 Ibidem, s. 408.

125 Ibidem, s. 411.

126 P. Kładoczny, Prawo jako narzędzie represji w Polsce Ludowej 1944-1956, Warszawa 2004, s. 176-177. 
Kto, działając na rękę władzy okupacyjnej niemieckiej: a) brał lub bierze udział w dokonywaniu zabójstw osób z pośród ludności cywilnej lub jeńców wojennych, w znęcaniu się nad nimi albo ich prześladowaniu, b) działał lub działa na szkodę osób przebywających na obszarze Państwa Polskiego, w szczególności przez ujęcie lub wywożenie osób poszukiwanych albo prześladowanych przez władzę okupacyjną z jakichkolwiek przyczyn (z wyłączeniem ścigania za dokonanie przestępstw pospolitych) ${ }^{127}$

i normę sankcjonowaną - karę śmierci. Były dyrektor Głównej Komisji Badania Zbrodni Hitlerowskich w Polsce Czesław Pilichowski ustalił, że na podstawie Dekretu sierpniowego w latach 1944-1970 skazano w Polsce 5340 zbrodniarzy niemieckich, co stanowi tylko 34\% ogółu ${ }^{128}$.

W tym miejscu wskazać należy, że w przypadku wyroku Arthura Gresiera jako podstawę jego skazania wymieniono szereg wskazanych wyżej przepisów obowiązującego kodeksu karnego z 1932 r. w zbiegu z art. 1 Dekretu „o wymiarze kary dla faszystowsko-hitlerowskich zbrodniarzy winnych zabójstw i znęcania się nad ludnością cywilną i jeńcami oraz dla zdrajców Narodu Polskiego". Dzięki temu rozwiązaniu polskie prawo karne uzupełnione zostało o Dekret dostosowany do wydarzeń okresu okupacji. Mimo ułatwienia w postaci otrzymania specjalnych przepisów, stworzonych do sądzenia ogromu zbrodni popełnionych na ziemiach polskich w czasie II wojny światowej, Dekret sierpniowy był z jednej strony zaprzeczeniem jednej z podstawowych zasad prawa - lex retro non agit, natomiast z drugiej był zgodny z kształtującymi się zasadami norymberskimi. Ponadto zaznaczyć trzeba, że skazanie na podstawie przepisów kodeksu karnego w związku z Dekretem z 31 sierpnia 1944 r. prowadziło też do zaostrzenia kary (w stosunku do odpowiedzialności oskarżonego tylko na podstawie kodeksu karnego) przez obowiązywanie normy sankcjonowanej z Dekretu, tj. kary śmierci.

Szczególnej uwagi wymaga prawniczo prekursorskie orzeczenie Najwyższego Trybunału Narodowego, w którym po raz pierwszy w historii skorzystano z konstrukcji kwalifikacji przestępstwa określanej w terminologii anglosaskiej jako genocide. Catherine Epstein zaznacza, że co prawda użyto zwrotu „nowe zbrodnie przeciwko interesom ludzkości”, jednakże wywód Trybunału dotyczący charakteru przestępstw wskazuje, że Arthur Greiser winnym był czynów określanych w późniejszych wyrokach zamykających proces norymberski (1 października 1946 r.) jako ludobójstwo ${ }^{129}$. Przyjęto zatem konstrukcję odpowiedzialności za zbrodnie przeciwko ludzkości i wojenne także tych, którzy nie dokonywali przestępstw przeciwko życiu i zdrowiu osobiście. Przypomnieć należy, że w akcie oskarżenia przedłożonym norymberskiemu Trybunałowi:

127 Dz.U. z 1944 r. nr 4, poz. 16.

128 Cz. Pilichowski, Trybunat Norymberski i zasady norymberskie, a sprawa ścigania i karania hitlerowskich zbrodniarzy wojennych w latach 1945-1971, Warszawa 1971, s. 9.

129 C. Epstein, op.cit., s. 321. 
[oskarżeni] kierowali przemyślanym i systematycznym ludobójstwem (genocide), tj. eksterminacją grup rasowych i narodowych, dokonanym na ludności cywilnej na czasowo okupowanych terytoriach w celu wyniszczenia określonych ras i klas ludzkich i grup narodowych, rasowych i religijnych, w szczególności Żydów, Polaków, Cyganów i innych ${ }^{130}$.

Najwyższy Trybunał Narodowy uznał też, że III Rzesza dokonała „,najazdu przestępnego" i bezprawnie zajęła obszar należący do Polski. Jak zwraca uwagę Catehrine Epstein, „miało to duże znaczenie, ponieważ zgodnie z Kartą Międzynarodowego Trybunału Wojskowego »zbrodnie przeciwko ludzkości« mogą być przedmiotem rozprawy tylko wtedy, gdy bezpośrednio dotyczą »zbrodni przeciwko pokojowi«"131.

Już 21 lipca 1946 r. o 7 rano, o czym donosiła prasa, odbyła się publiczna egzekucja na stokach poznańskiej cytadeli ${ }^{132}$. Wzbudziła ona żywe zainteresowanie wśród mieszkańców Poznania, którzy śledzili ją naocznie bądź za pośrednictwem mediów. Dziennikarz „Głosu Wielkopolskiego” pisał:

W niedzielę tłumy zaczęły zbierać się już przed godziną 6 rano u wylotu alei Pułaskiego. Ostatecznie zgromadziło się prawdopodobnie około 100 tysięcy ludzi. Dziennikarze dokładnie opisują procedurę egzekucji. Na miejsce przyjeżdża samochód oznaczony jako auto PCK. Wyprowadzony z niego zostaje skazany, słaniając się na nogach prowadzony jest pod szubienice. Następuje odczytanie wyroku i sprawdzenie tożsamości skazanego ${ }^{133}$.

Obóz karno-śledczy w Żabikowie, jak wskazują najnowsze badania, stał się miejscem śmierci ponad 500 osób i miejscem utraty zdrowia dla kolejnych setek czy tysięcy ludzi. Do momentu rozpoczęcia procesu Arthura Greisera w obozie przeprowadzono cztery wizje lokalne, z których dwie połączone były z pracami ekshumacyjnymi wykonywanymi pod auspicjami poznańskiego Oddziału Komisji Badania Zbrodni Niemieckich w Polsce bądź przez jej późniejszych członków. Badania prowadzone przez dra Stanisława Łagunę, a także przez innych pracowników i członków Komisji, pozwoliły uzyskać obszerny materiał dowodowy w postaci przeprowadzonych ekshumacji i licznych zeznań świadków. Informacje zebrane w protokołach stały się jednymi z najważniejszych dowodów przedstawionych przez oskarżenie przeciwko Arthurowi Greiserowi, który także za zbrodnie w obozie karno-śledczym skazany został na karę śmierci. Prace przeprowadzone w Żabikowie przez Komisję Badania Zbrodni Niemieckich w Polsce przyczyniły się do osądzenia i skazania tylko jednej (wobec nieuchwycenia żad-

\footnotetext{
130 J. Sawicki, Ludobójstwo. Od pojęcia do konwencji 1933-48, Kraków 1949, s. 25-26.

131 C. Epstein, op.cit., s. 320.

132 Jutro o godz. 7 rano Greiser zawiśnie na szubienicy, „Głos Wielkopolski”, 20 lipca 1946 r.

133 Arthur Greiser zostat powieszony, „Głos Wielkopolski”, 21 lipca 1946 r.
} 
nego ze strażników obozu) z grona osób odpowiedzialnych za zbrodnie dokonywane na osadzonych tam więźniach.

Sprawa zbrodni w obozie karno-śledczym w Żabikowie i związany z tym proces Arthura Greisera to modelowy przykład działalności nowo utworzonego polskiego systemu ścigania i sądzenia najważniejszych zbrodniarzy nazistowskich. Wskazane powyżej składowe całego procesu, omówienie ich działania i skuteczności, pozwalają na udzielenie odpowiedzi na zawarte w tezie pytania. Przyglądając się etapom tworzenia kolejnych instytucji, których działanie wykorzystane zostało w procesie Arthura Greisera, wskazać należy, że powstawały one raczej jako odpowiedź na konkretne zapotrzebowania niż jako całościowy, przemyślany system pozwalający na ściganie i sądzenie zbrodniarzy nazistowskich. Mimo to z przedstawionych powyżej informacji można wnioskować o sprawności i skuteczności całego systemu, który pozwolił na ekstradowanie byłego gauleitera Kraju Warty do Polski, zebranie koniecznych dowodów do postawienia aktu oskarżenia i w końcu na przeprowadzenie procesu.

Mimo że każdy z elementów, tworzących potrzebną do osądzenia Arthura Greisera całość, powstawał osobno, a także mimo że każdy posiadał mniej lub bardziej poważne wady prawne czy organizacyjne, kolejne etapy, od pochwycenia zbrodniarza do jego skazania, odbywały się sprawnie i fachowo. Mimo skrajnie trudnych warunków lat powojennych, rządzona przez komunistów Polska, która wraz z upływem kolejnych lat oddalała się od standardów państwa demokratycznego, potrafiła skutecznie ścigać i sądzić zbrodniarzy nazistowskich.

Na pozytywną ocenę zasługuje także Najwyższy Trybunał Narodowy, który z uwagi na status sądu specjalnego i codziennie odbywające się rozprawy przyczynił się do sprawnego sądzenia oskarżonych. Mimo zatem, że w przypadku braku NTN, zbrodniarze i tak stanęliby przed sądami, tyle, że powszechnymi, to na końcowe rozstrzygnięcie czekać należałoby prawdopodobnie dłużej, a doniosłość procesu byłaby niższa.

W opinii autora największą w tej kwestii zasługę odbiera jednak Główna Komisja Badania Zbrodni Niemieckich w Polsce ze swą ekspozyturą - Wojskową Misją Badania Zbrodni Wojennych w Europie. Rysujący się konflikt na linii ZSRR i USA, w który angażowane były też kraje sojusznicze, stanął na drodze ekstradowania do Polski większej liczby zbrodniarzy. Trudno za ten stan rzeczy winić Misję, a także Główną Komisję, dzięki której zebrano olbrzymią ilość dowodów, będących następnie podstawą aktów oskarżenia. W ocenie autora dwie wskazane wyżej instytucje są najjaśniejszymi punktami utworzonej i wypracowanej procedury ścigania i sądzenia zbrodniarzy wojennych. Ogromny wysiłek, ważny czynnik społeczny i duże zaangażowanie oddawały w ręce prokuratora efekt swojej pracy, który w procedurze karnej jest najtrudniejszy i najbardziej pracochłonny - zebranie dowodów pozwalających na sporządzenie oskarżenia. 
EVALUATION OF THE EFFICIENCY OF THE POLISH POST-WAR JUSTICE SYSTEM IN THE ADJUDICATION OF INTERNATIONAL LAW CRIMES AS EXEMPLIFIED BY WORK CARRIED OUT BY THE CENTRAL COMMISSION FOR THE INVESTIGATION OF GERMAN CRIMES IN POLAND IN THE PENAL-INVESTIGATION CAMP IN ŻABIKOWO AND ITS USE IN THE TRIAL OF ARTHUR GREISER

\section{Summary}

The paper constitutes an evaluation of a fragment of activity of the Polish justice system connected with the adjudication of international law crimes directly after the Second World War. The purpose of this article is to demonstrate whether the new Polish authorities, who were building the framework of a socialist state, managed to create an efficient system of prosecution and judgement of Nazi war criminals. In order to answer thus delineated thesis, the paper presents the activity of different parts of the formed system as exemplified by the investigation of crimes committed in the penal-investigation camp in Żabikowo and the trial of Arthur Greiser connected with it. The system was comprised of the Central Commission for the Investigation of German Crimes in Poland, the Military Mission for Investigation of War Crimes in Europe as well as the Supreme National Tribunal. The result of the conducted research is a positive evaluation of the functioning of the justice system in relation to the prosecution and judgement of international law criminals. The article deals with an issue which was only described by articles of significance in the Polish People's Republic. Undertaking this subject matter from the modern point of view seems justified and necessary. Furthermore, providing an answer to the thesis also brought to light previously unpublished documents. The answer was provided on the basis of a particular example of crimes committed in the penal-investigation camp in Żabikowo while the unpublished documents were created by the Central Commission for the Investigation of German Crimes in Poland.

\section{ÉVALUATION DE L'EFFICACITE DU SYSTEME JUDICIAIRE POLONAIS D'APRES-GUERRE DANS LE JUGEMENT DES CRIMES DE DROIT INTERNATIONAL À L'EXEMPLE DE L'ENQUÊTE MENÉE PAR LA COMMISSION D'INVESTIGATION DES CRIMES ALLEMANDS EN POLOGNE DANS LE CAMP PÉNITENTIAIRE ET D'INVESTIGATION À ŻABIKOWO ET SES RÉSULTATS PRÉSENTÉS AU TRIBUNAL LORS DU PROCÈS D'ARTHUR GREISER}

\section{Résumé}

L'article est une analyse d'un élément du fonctionnement du système judiciaire polonais immédiatement après la Seconde Guerre mondiale, lié au jugement des crimes de droit international. L'objectif de cette étude est de démontrer si les nouvelles autorités polonaises, qui ont jeté les bases de l'État socialiste, ont réussi à créer un système efficace de poursuites et de jugement des criminels nazis. Pour répondre à une telle thèse, l'article présente le fonctionnement des composants du système, à savoir: la Commission 
d'investigation des crimes allemands en Pologne, les enquêtes militaires sur les crimes de guerre en Europe et le Tribunal national suprême, à l'exemple des enquêtes sur les crimes commis dans le camp pénitentiaire et d'investigation à Żabikowo et le procès d'Arthur Greiser qui a été impliqué dans ces crimes. La recherche menée a pour résultat une évaluation positive du fonctionnement du système judiciaire, en ce qui concerne les poursuites et le jugement des criminels de droit international. L'article traite des questions sur lesquelles des publications considérables n'ont été parues que sous la République populaire de Pologne. Faire l'analyse de ce sujet dans la perspective moderne semble être justifié et nécessaire. De plus, la tentative de répondre à la thèse contenue dans le titre, en basant sur un exemple spécifique des crimes commis dans le camp pénitentiaire et d'investigation à Żabikowo, permettait la divulgation des documents non publiés établis par la Commission d'investigation des crimes allemands en Pologne. 